\title{
Látlelet a hazai közgazdasági felsőoktatásról az egyetemek fenntartóváltása előtt
}

\begin{abstract}
A hazai felsőoktatás alapvető változások előtt áll, az állami egyetemek alapítványi formában történő jövőbeli müködése új feltételek közé helyezi a közgazdasági képzéseket is. De nemcsak a fenntartóváltás, hanem a külföldi egyetemek elszívó hatása, a képzésbe belépő generációk korábbiaktól eltérő elvárásai, a hibrid oktatás elötérbe kerülése stb. egyaránt új kihívások elé állítják az intézmények vezetését és az oktatókat. Tanulmányomban a fenntartóváltás előtti helyzetet tekintem át, az elmúlt másfél évtizedben a gazdaságtudományi (másképpen közgazdasági) képzési területen megfigyelhető alapvető folyamatokat, a többciklusú felsőoktatási (az úgynevezett bolognai) rendszer 2006-os bevezetésétől egészen 2020-ig. Magyarországon a gazdaságtudományi képzési terület az egyik legnépesebb, a hallgatók negyedét közgazdasági szakokra veszik fel, a felsőoktatási szakképzéstől az alapképzésen át a mesterképzésig. De az egyik legkiterjedtebb is, hiszen például közgazdasági alapképzést jelenleg is 29 intézmény folytat 31 városban. ${ }^{*}$

Journal of Economic Literature (JEL) kód: A20, H52, I23.
\end{abstract}

„Nincs ország, ahol több lenne a te-
hetség, mint éppen magyar földön, de
egyúttal nincs ország, ahol a tehetség
nehezebben tudna teljes kifejlődéshez
jutni, mint éppen miközöttünk.”
Klebelsberg Kunó

\section{A hazai felsőoktatás átalakulása az elmúlt három évtizedben}

Az 1990-es évek elejétől a felsőfokú képzések, átképzések iránti igények rohamosan nőttek, ami a hazai felsőoktatásban is gyökeres átalakulást indított el (DerényiTemesi [2016], Polónyi-Kozma [2020], Veres [2015]). A rendszerváltás előtt inkább

* A tanulmány korábbi változatát 2021. június 3-án tartott együttes ülésén megvitatta az MTA IX. Gazdaság- és Jogtudományok Osztályának Gazdálkodástudományi, Közgazdaság-tudományi és Regionális Tudományok Bizottsága. Az ülésen és azt követően sok hasznos megjegyzést és észrevételt kaptam, amit ezúton is köszönök.

Lengyel Imre egyetemi tanár, SZTE Gazdaságtudományi Kar (e-mail: ilengyel@eco.u-szeged.hu). A kézirat első változata 2021. június 25-én érkezett szerkesztőségünkbe.

DOI: http://dx.doi.org/10.18414/KSZ.2021.10.1055 
„elitképzésként” funkcionáló felsőoktatás fokozatosan „tömegesedő képzéssé” vált, a hallgatók összlétszáma az 1990-es 108 ezerről a csúcsot jelentő évben, 2005-ben 424 ezer före nőtt, majd fokozatosan mérséklődve 2020-ban 287 ezer före csökkent. Nemcsak nappali tagozaton figyelhető meg a rendszerváltás utáni felsőoktatási expanzió, hanem a részidős (levelező, esti, táv-) oktatásban és a felsőfokú végzettséget nem adó szakirányú tovább- és átképzésekben, illetve felsőoktatási (2013-ig felsőfokú) szakképzésekben is. Főleg a kiépülő piacgazdaság által támasztott munkaerőpiaci igények generálták ezt a felsőoktatási expanziót, amely az idősebb munkavállalók átképzésében is tetten érhetö, és amit felerősített a lakosság korábban elfojtott „diploma iránti vágya" is. A gazdaságtudományi képzések iránti kereslet is szinte robbanásszerüen nőtt, és még napjainkban is igen élénk.

A hallgatók összes létszámán belül a felsőfokú végzettséget (a köznyelvben diplomát) nyújtó képzéseké igen dinamikusan nőtt, 1990-től 2005-ig 102 ezerről 381 ezer före, ezt követöen fokozatosan visszaesett, 2016-tól 240-250 ezer fö között ingadozik (1. ábra). A nappali tagozatos magyar állampolgárságú hallgatók létszáma 1990-ben 73 ezer fő volt, ütemesen bővülve 2007-ben 216 ezer föt ért el, majd fokozatosan mérséklödött 2020-ban 155 ezer före. A részidős oktatásban részt vevők száma dinamikusabban változott, míg 1990-ben 26 ezer fő volt, addig 2005-ben már 163 ezer fö, innen csökkent le, és 2016-tól 60-61 ezer között stagnál, föleg a munkában állók képzésének, átképzésének lecsengése következtében. Az új belépők (elsősök) száma 2013-tól viszonylag stabil, 43-46 ezer fö közötti. Az is megfigyelhetö, hogy a nappali tagozatos külföldi hallgatók létszáma fokozatosan emelkedik, 2020-ban elérte a 32 ezer föt.

A felsőfokú végzettséget adó gazdaságtudományi képzések ${ }^{1}$ korábban igen visszafogottak voltak, 1990-ben mindössze 9,5 ezer fö volt a hallgatók száma (a nappalis hallgatóknak körülbelül 6 százaléka járt közgazdasági szakra), amely dinamikusan növekedve 2005-ben már 87,3 ezer föt ért el, másfél évtized alatt a kilencszeresére nőtt, miközben az összes képzésé csak háromszorosára. A nappali tagozatos hallgatók létszáma az 1990-es 4,8 ezer főről 2010-ben 38,9 ezer főre nőtt, majd a 2018-as 24,8 ezerre mérséklődött. A részidősöké 4,7 ezerről 2005-ben 55,0 ezer főre növekedett, ebben az évben a részidős hallgatók harmada közgazdasági képzésre járt, ezt követően rohamosan csökkent a 2018-as 15 ezer före.

Magyarországon gazdaságtudományi képzések 1990 elött csak néhány felsőoktatási intézményben voltak. Egyetemi szintü közgazdasági képzések az 1948-ban alapított Marx Károly Közgazdaságtudományi Egyetemen (jogutódja a Budapesti Corvinus Egyetem), majd az 1970-es évektöl Pécsett, az 1980-as évektől Miskolcon, főiskolai szintủ képzések pedig több budapesti föiskolán (Pénzügyi és Számviteli Főiskola, Kereskedelmi és Vendéglátóipar Főiskola, Külkereskedelmi Főiskola) folytak, továbbá vidéki tagozataikon is. Az egyetemi négy-öt éves képzések végén okleveles közgazdász, a három-négy éves föiskolai képzés végén általában üzemgazdász

\footnotetext{
${ }^{1}$ Hivatalos elnevezése gazdaságtudományi képzési terület, amelyre alkalmanként a hétköznapi „közgazdasági” kifejezést használom, amelyen belül majd elkülönítjük a közgazdaságtani és az üzleti (gazdálkodástani) képzéseket.
} 
1. ábra

A felsőfokú végzettséget nyújtó alap- és mesterképzés hallgatóinak létszáma, 1990-2020 (ezer fö)

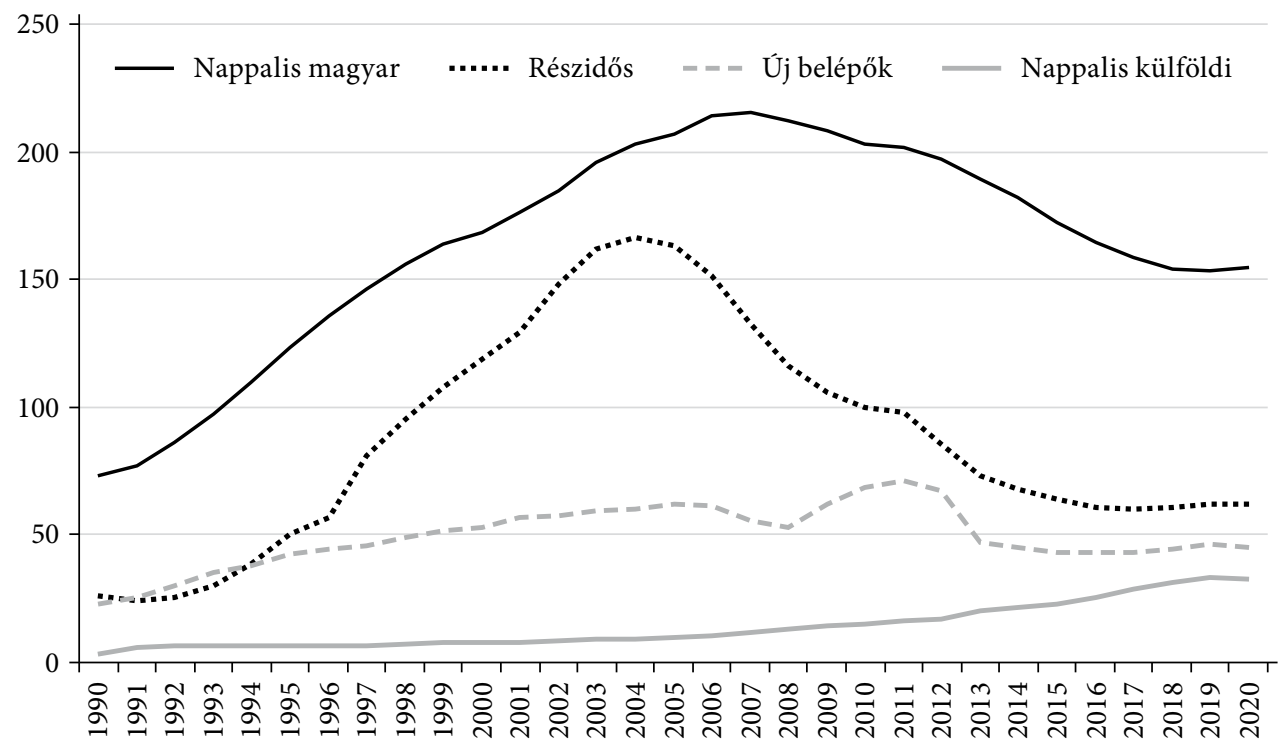

Megjegyzés: 2012-ig elsősök, 2013-tól új belépők.

Forrás: KSH Stadat 23.1.1.21. tábla alapján saját számítás.

diplomát lehetett kapni, a posztgraduális képzésekben pedig szakközgazdász, illetve szaküzemgazdász okleveleket.

A rendszerváltozást követően az addig átpolitizált közgazdaságtani, üzleti ismeretanyag modernizálódott, és az állami felsőoktatási intézmények többségében megszerveződtek a gazdaságtudományi (közgazdasági) képzések. Korábban mindegyik felsőoktatási intézmény minden egyes szakán kötelező tárgy volt például a politikai gazdaságtan, amely tárgy oktatói egy átképzést követően mikro- és makroökonómiát taníthattak. A müszaki és agrárképzésekben korábban is több módszertani alapozó ismeretanyag (matematika, informatika, statisztika stb.) szerepelt, sőt vezetés-szervezés, termelésmenedzsment, beruházásgazdaságossági számítások stb. tárgyak is. Mivel az oktatók egy része rendelkezésre állt, az 1990-es években a piacgazdaság kiépülésével párhuzamosan a közgazdaságtani és üzleti ismeretek iránt megnyilvánuló növekvő igényekre viszonylag könnyen tudtak reagálni az intézmények (a tudományegyetemeken kívül szinte az összes tanár- és tanítóképző, agrár- és müszaki föiskola stb.). A képzések gyorsan megszervezhetők és alacsony költséggel elindíthatók voltak (nem kellettek laborok, drága müszerek stb.).

A felsőoktatást feszítő problémákat menet közben érzékelve kisebb-nagyobb átszervezések (például integrált intézmények kialakítása) történtek, köztük a legjelentősebb, amikor Magyarország is csatlakozott az Európai Felsőoktatási Térséghez, a jelenleg 48 országot átfogó úgynevezett bolognai folyamathoz (Kováts-Temesi [2018], Hrubos [2019]). Hosszabb előkészítés után 2006-tól széles körben vezették be Magyarországon is a többciklusú felsőfokú oktatási rendszert, amely a gazdaságtudományi képzési területen is alapvető változásokat indított el. 
A nemzeti felsőoktatásról szóló 2011. évi CCIV. törvény (Nftv.) hatályos változata szerint:

„[A] felsőoktatási intézmény oktatási alaptevékenysége magában foglalja a felsőoktatási szakképzést, alapképzést, mesterképzést, a doktori képzést és a szakirányú továbbképzést." (Nftv. 2. paragrafus 3. bekezdése.)

A felsőoktatási szakképzésben és szakirányú továbbképzésben nem szerezhető felsőfokú végzettség, csak szakképzettség, amelyet oklevél tanúsít. Az alapképzésben 180, míg mesterképzésben 120 kredit a felsőfokú végzettség (diploma) elnyerésének egyik feltétele. Az indítható szakok körét, képzési és kimeneti követelményeit miniszteri rendelet szabályozza, az intézmények szakalapítási és szakindítási kérelmét a Magyar Akkreditációs Bizottság véleményezi és az Oktatási Hivatal engedélyezi.

Magyarországon az alapképzések többsége 2006-ban indult (néhány informatikai és müszaki képzésnél korábban), míg ezt követően a mesterképzések 2009-től (levelezőn korábban is) kezdődtek meg, de érdemben 2010-től, miután az alapképzésben széles körben kiadták a „bolognai” diplomákat. Az alapképzések általában 6-8 félévig, az általános mesterképzések 4 félévig, a mesterképzéshez sorolt osztatlan képzések (például orvosi, gyógyszerész-, jogász-) 10-12 félévig, a felsőoktatási szakképzések 4 félévig, míg a szakirányú továbbképzések 2-4 félévig tartanak (a doktori képzéssel ebben a tanulmányban nem foglalkozunk). A hazai szabályozás szerint felsőoktatási szakképzést és alapképzést nappali, levelezős, esti és távoktatás keretében egyaránt lehet folytatni, mester- és osztatlan képzést nappali, esti és levelező tagozatokon, míg szakirányú továbbképzést csak levelezős formában.

A hazai felsőoktatás intézményrendszere is átalakult, a többször módosított Nftv. (9. paragrafus 3. bekezdése) 2016-tól háromféle típust különít el:

- Egyetem: legalább nyolc alapképzési és hat mesterképzési szakon jogosult képzésre, valamint doktori képzésre és doktori fokozat odaítélésére. Munkaviszony, illetve közalkalmazotti jogviszony keretében foglalkoztatott oktatóinak, kutatóinak legalább hatvan százaléka tudományos fokozattal rendelkezik, képzéseit képes idegen nyelven folytatni az általa indított szakok egy részén.

- Alkalmazott tudományok egyeteme: legalább négy alapképzési szakon és két mesterképzési szakon jogosult képzésre, legalább két szakon duális képzést folytat. Munkaviszony, illetve közalkalmazotti jogviszony keretében foglalkoztatott oktatóinak, kutatóinak legalább negyvenöt százaléka tudományos fokozattal rendelkezik, képzéseit képes idegen nyelven folytatni az általa indított szakok egy részén.

- Föiskola: munkaviszony, illetve közalkalmazotti jogviszony keretében foglalkoztatott oktatóinak, kutatóinak legalább harmada tudományos fokozattal rendelkezik.

Magyarországon 2020 őszén 64 álla milag elismert felsőoktatási intézmény létezett: 19 állami, 21 egyházi és 24 egyéb alapítványi intézmény. Közülük 32 folytat gazdaságtudományi képzést is, a 2021-es felvételi tájékoztató szerint 40 városban mint képzőhelyen (Függelék F1. táblázat) ${ }^{2}$ :

\footnotetext{
${ }^{2}$ A továbbiakban az intézményeknek a Függelék F1. táblázatában szereplö rövidítését használjuk.
} 
- 17 egyetem: a 15 állami egyetemből tízben van gazdaságtudományi képzés, a 14 nem államiból hétben (köztük 2021 előtt fenntartóváltáson átesett: BCE, ME, SOE, SZE),

- 10 alkalmazott tudományok egyeteme (szakegyetem): ${ }^{3}$ mind a négy állami és hat nem állami intézményben (köztük a 2021 elött fenntartóváltáson átesett NJE-n) létezik gazdaságtudományi képzés és

- 5 föiskola: az egyetlen államiban, míg a 24 nem államiból négyben működik gazdaságtudományi képzés.

A gazdaságtudományi képzések a többciklusú rendszerre történt áttérést követően továbbra is népszerüek maradtak. Az alapképzéseknél 2006 és 2011 között 16-17 ezer főt vettek fel évente, ez a szám 2012-ben leesett kétharmadára, ezt követően 10-11 ezer fö között mozgott, részarányuk az összes alapképzést tekintve 2020-ban 24 százalékot ért el. Felsőoktatási szakképzésre is jelentős számú hallgató kerül, évente 4-5 ezer fö, az összes hallgató kétharmada gazdaságtudományi szakokra jár, ezek a hallgatók az alapképzés egyféle potenciális bázisát is jelentik. A közgazdasági mesterképzésekre felvettek létszáma viszonylag stabilnak tekinthető, négyezer fő körül ingadozik, részarányuk 20-22 százalék. Osztatlan képzés (ötéves) gazdaságtudományi képzési területen csak 2017-től indult, gazdaság- és pénzügy-matematikai elemzés szakon, egyetlen intézményben és csak nappali tagozaton (BCE), ahol 2020-ban 61 föt vettek fel.

A tanulás eredményes befejezése után kiadott, felsőfokú végzettséget igazoló oklevelek száma az összes képzést tekintve 1990-1994 között évente 24-25 ezer volt, amely fokozatosan emelkedve 2005-ben 57 ezret ért el, onnan csökkent le kisebb ingadozásokkal a 2017 után megfigyelhető 50 ezerre. Meg kell jegyeznünk, hogy egy hallgató ötévi tanulás után két oklevelet kaphat, az elsőt az alap-, a másodikat pedig a mesterképzést befejezve. A kiadott oklevelek száma jóval alacsonyabb, mint amennyi várható lenne a felvettek számát tekintve. Például a 2009 és 2011 között felvett hallgatók adatai szerint gazdaságtudományi alapképzéseknél 52-54 százalékos a sikeres befejezés, 34-36 százalékos a lemorzsolódás, 9-10 százalékos a kilépés, míg néhányan még folytatják tanulmányaikat (Demcsákné Ódor-Huszárik [2020] 47. o.). Ez az arány jelentősen javulhat, mivel 2020-ban nyelvvizsga-követelmény nélkül is lehetett kérvényezni a beragadt diplomák kiadását.

A lemorzsolódás összefügg a hallgatók nagyarányú munkavállalásával is. Az Európai Bizottság jelentése szerint a felsőoktatás egészét tekintve

„a hallgatók több mint negyede legalább egy évre megszakítja tanulmányait munkavégzéssel kapcsolatos okokból. A magyar hallgatók több mint egyharmada egész évben, így a vizsgaidőszakokban és az oktatási szünetekben is dolgozik (Eurostudent [2018]). A fizetett állással rendelkező hallgatók átlagosan heti 35 órát dolgoznak, és e munkáknak csak a fele kapcsolódik szorosan a tanulmányaikhoz." (EU [2018] 9. o.)

\footnotetext{
${ }^{3} \mathrm{Az}$ alkalmazott tudományok egyeteme elnevezés helyett a továbbiakban a rövidebb szakegyetemet használjuk.
} 
A hallgatói létszám 1990 utáni jelentős növekedése komoly kihívások elé állította a felsőoktatási intézményeket, mivel sem a személyi, sem az anyagi feltételek nem követték ezt a bővülést. Például az oktatók létszáma 1990-ben 17,3 ezer fö volt, amely 2004-ig fokozatosan 23,8 ezer före nött, ezt követöen kissé lecsökkent, 2012-ben 20,6 ezer före, majd 2016 után stabilizálódott 22-23 ezer fö között, közülük 15 ezer fóállású oktatóval (KSH Stadat 23.1.1.20. tábla). A hallgatói létszám 1990-hez képest még nappali tagozaton is több mint két és félszeresére nőtt (a külföldi hallgatókat is beleértve), s ettől nagyon elmaradt az oktatói létszámok növekedése.

A hallgatói létszámban bekövetkezett változásokat azonban nem követték a költségvetés felsőoktatási kiadásai, amelyek a GDP-hez viszonyítva a 2001-es 1,05 százalékról 2005-ben - a maximális hallgatói létszám évében - 1,01 százalékra csökkentek, majd 2011-ben tovább mérséklődtek 0,95 százalékra, és 2013-tól évente 0,80 százalék körül mozognak (KSH Stadat 23.1.1.2. tábla). Az önköltséges képzések viszonylag magas aránya és a továbbtanulás egyéb kiadásainak növekedése arra vezetett, hogy nemzetközi összehasonlításban Magyarországon

„a felsőoktatásban való részvétel támogatásához igénybe vett magánforrások aránya a harmadik legmagasabb az Unióban" (EU [2018] 9. o.).

A költségvetési és a magánforrások együtt 2019-ben a GDP 1,1 százalékát tették ki, ami közel van az 1,2 százalékos EU-átlaghoz (OECD [2020]). A 2000 -es évek elején az állami és a magánszféra együttes részvételét (public-private partnership, PPP) javasolták a szűkös felsőoktatási források enyhítésére - egyetemi kollégiumok, oktatási épületek, irodák építésére és fenntartására -, amelynek fedezetét a tervek szerint főleg a hallgatók költségtérítése nyújtotta volna. A tandíjról szóló 2008-as népszavazás következményei - a zömében költségtérítéses részidős hallgatói létszám visszaesése - azonban ezeket az elképzeléseket ellehetetlenítette, több intézmény anyagilag nehéz helyzetbe került, és emiatt összevonások történtek. ${ }^{4}$

A felsőoktatás jelentős bővülése ellenére a hallgatók aránya az össznépességhez viszonyítva 2018-ban Magyarországon 2,9 százalék, az EU átlaga 3,9 százalék, a 28 tagállam közül csak Románia, Szlovákia és Luxemburg aránya alacsonyabb (KSH Stadat 23.1.3.1. tábla). Az EU-ban 2019-ben a munkavállalási korúak, azaz a 25-64 évesek közül 11,3 százalék tanult a felsőoktatásban (a skandináv államokban 25-30 százalék), Magyarországon mindössze 5,8 százalék (Eurostat [SDG_04_60]). Ezzel az aránnyal Magyarország jelentősen elmarad Észtországtól (20,2 százalék), Szlovéniától (11,2 százalék) és Csehországtól (8,1 százalék), de megelőzi például Lengyelországot (4,8 százalék) vagy Szlovákiát (3,6 százalék). Úgy tủnik, hogy a továbbképzések, az élethosszig tartó tanulás Magyarországon kevésbé elfogadott, amit jelez a részidős képzések korábban bemutatott jelentős visszaesése is. Sem a munkaadók, sem a munkavállalók nem preferálják a továbbképzéseket, átképzéseket, legalábbis nem a hazai felsőoktatási intézményekben. A hallgatói létszám emelkedése következtében megnőtt a diplomások aránya, az Európa 2020-célkitüzések között is az szerepel, hogy 30-34 évesek 40 százaléka rendelkezzen felsőfokú oklevéllel (ISCED 5-8. szint).

\footnotetext{
${ }^{4}$ Később az állami költségvetés a felsőoktatási PPP-konstrukciók többségét kiváltotta.
} 
Magyarországon is jelentős a növekedés, amíg 2000-ben a 30-34 évesek 14,8 százaléka volt diplomás, addig 2020-ban már 33,2 százaléka - az EU27 átlaga 40,9 százalék (Eurostat [T2020_41]) -, de csak két országban kisebb ez az arány, Olaszországban (27,8 százalék) és Romániában (26,4 százalék).

Három évtized alatt a hazai felsőoktatási intézmények hallgatóinak létszáma egy jelentős felfutást követően mérséklődött, és elsősorban a külföldi hallgatóknak tudható be, hogy nem nagyobb mértékben. Napjainkban csak mintegy kétszer annyi magyar állampolgár tanul hazai felsőoktatási intézmények nappali tagozatain, mint 1990-ben. Részidősöknél is alig haladja meg a korábbi létszám kétszeresét, ami azt is jelzi, hogy az élethosszig tartó tanulás még nem nyert teret. A létszám alakulását alapvetően befolyásolta a demográfiai folyamat, 2000 és 2010 között évente körülbelül 90 ezer fö érettségizett, majd fokozatosan lecsökkent a számuk 67-68 ezer före. Természetesen a jelentkezésekre hat a középiskolákban szerezhető tudás színvonala, az át- és továbbképzési hajlandóság, a tandíjjal kapcsolatos viták, az oktatáspolitikai döntések, az élethosszig tartó tanulás motivációja, a külföldi továbbtanulási lehetőségek, az alacsony társadalmi mobilitás stb. is. A közgazdasági képzések népszerüsége töretlen, a felvett hallgatók negyede ezekre a szakokra kerül be.

\section{A gazdaságtudományi alapképzés}

A tanulmány írásakor hatályban levő, a képzési és kimeneti követelményeket megfogalmazó, legutóbb 2020 decemberében módosuló 18/2016. (VIII. 5.) EMMIrendeletben gazdaságtudományok képzési területen nyolc alapképzési szak található (1. táblázat). A többciklusú képzési rendszer 2006-os bevezetésekor az alapszakokat két csoportba, közgazdaságtani és üzleti (gazdálkodástani) típusokba sorolták. Elemzésünkben az üzleti szakoktató képzéseket nem vesszük figyelembe, véleményem szerint nem alap-, hanem inkább mesterszakosnak kellene lenniük.

Kezdetben három közgazdaságtani alapszak szerepelt: alkalmazott közgazdaságtan, gazdaságelemzés és közszolgálati. Mindhárom alapszakot több egyetem meghirdette, például az alkalmazott közgazdaságtan alapszak 2017-ben még öt egyetemen (BCE, BMGE, ELTE, PE, PTE) indult, mára csak a BCE-n maradt fenn. A gazdaságelemzés nappali tagozaton a BCE-n, levelező tagozaton a SZIE-n (2009 és 2012 között) indult, 2014-től gazdaság- és pénzügy-matematikai elemzés néven futott (csak a BCE-n indult), amely 2017-ben osztatlan képzéssé vált, de az alapszak is feltámadt 2021-től mint közgazdasági adatelemzés (a tanulmány lezárásakor még nem hirdette meg egyetlen intézmény sem). A közszolgálati alapszak is megszűnt 2013 után (korábban több intézmény indította, például BCE, BGE, DE, KRF, METU, SOE, SZE), föleg a Nemzeti Közszolgálati Egyetem (NKE) megszerveződése miatt. Tehát napjainkra csak egyetlen közgazdaságtani alapszak maradt talpon, egyetlen egyetemen (a BCE-n nappali tagozaton), ennek következtében 2020-ban a gazdaságtudományi alapképzésre felvett hallgatók 99 százaléka üzleti alapképzésre került. Tehát egyértelmüen látszik, hogy Magyarországon lényegében csak üzleti típusú (business school) alapképzések vannak (Barakonyi [2009]). 
1. táblázat

A gazdaságtudományi alapszakok és a felsőoktatási szakképzés fö jellemzői

\begin{tabular}{|c|c|c|c|c|c|c|}
\hline \multirow[t]{2}{*}{ Alapszakok } & \multirow{2}{*}{$\begin{array}{l}\text { 2021-ben } \\
\text { meghirdetett } \\
\text { intézmények } \\
\text { száma }^{*}\end{array}$} & \multirow{2}{*}{$\begin{array}{l}\text { Félévek } \\
\text { száma }\end{array}$} & \multirow{2}{*}{$\begin{array}{l}\text { Kreditek } \\
\text { száma }\end{array}$} & \multicolumn{3}{|c|}{ Felvett hallgatók száma 2020-ban } \\
\hline & & & & összes & $\begin{array}{c}\text { összesből } \\
\text { nappalis }\end{array}$ & $\begin{array}{c}\text { összesből } \\
\text { államilag } \\
\text { finanszírozott }\end{array}$ \\
\hline $\begin{array}{l}\text { Alkalmazott } \\
\text { közgazdaságtan }\end{array}$ & $1(1)$ & 6 & 180 & 110 & 110 & 105 \\
\hline Közgazdasági adatelemzés & - & 6 & 180 & - & - & - \\
\hline Emberi erőforrások & $11(0)$ & 7 & $180+30$ & 738 & 435 & 243 \\
\hline $\begin{array}{l}\text { Gazdálkodási és } \\
\text { menedzsment }\end{array}$ & $28(15)$ & 7 & $180+30$ & 3802 & 2891 & 1705 \\
\hline Kereskedelem és marketing & $14(4)$ & 7 & $180+30$ & 2123 & 1715 & 862 \\
\hline Nemzetközi gazdálkodás & $15(6)$ & 8 & $180+60$ & 1371 & 1234 & 921 \\
\hline Pénzügy és számvitel & $17(4)$ & 7 & $180+30$ & 1610 & 1204 & 860 \\
\hline Turizmus-vendéglátás & $17(9)$ & 8 & $180+60$ & 1521 & 1347 & 569 \\
\hline Alapszakok együtt & - & - & - & 11275 & 8936 & 5265 \\
\hline Felsőoktatási szakképzés & $25(0)$ & 4 & 120 & 4509 & 3062 & 3659 \\
\hline
\end{tabular}

* Zárójelben az idegen nyelven meghirdetettek szerepelnek.

** Matematikából emelt szintű érettségi.

Forrás: Felvi alapján saját számítás.

Az üzleti alapszakok köre a másfél évtized alatt nem változott, mindvégig fennmaradt a hat alapszak, és mindegyiket elindította több intézmény (1. táblázat). Kiemelkedik a szakok közül a gazdálkodási és menedzsment képzés, amelyet 2021-ben 28 intézmény meghirdetett (idegen nyelven is 15), de a többi alapszak is viszonylag sok helyen indul, és mindegyikre elég sok hallgatót tudtak felvenni 2020-ban. Az üzleti alapszakok két csoportba oszthatók a félévek száma és az oklevélhez szükséges nyelvtudás szerint, mindkét szempont fontos a folyamatok érdemi mérlegeléséhez. Megjegyzem, hogy a felvettek száma eltérhet a beiratkozottakétól, utóbbit az októberi jelentésben közlik az intézmények

Az emberi erőforrások, gazdálkodási és menedzsment, kereskedelem és marketing, valamint a pénzügy és számvitel alapszakok hét félévesek, ahol az utolsó félév szakmai gyakorlat (minimum 12 összefüggö hét). Ezeken a szakokon az oklevélhez egy idegen nyelvből államilag elismert középfokú (B2), komplex típusú, a képzési területnek megfelelö szaknyelvi vagy államilag elismert felsőfokú (C1), komplex típusú általános nyelvvizsga vagy ezekkel egyenértékü érettségi bizonyítvány vagy oklevél szükséges.

A nemzetközi gazdálkodás és a turizmus-vendéglátás alapszakok nyolc félévesek, és jellegükből adódóan nyelvigényesek: két idegen nyelvből államilag elismert középfokú (B2), komplex típusú, a képzési területnek megfelelő szaknyelvi nyelvvizsga vagy ezekkel egyenértékü érettségi bizonyítvány vagy oklevél szükséges, amelyek közül az egyik nyelvvizsga államilag elismert felsőfokú (C1), komplex típusú általános nyelvvizsgával 
kiváltható. Turizmus-vendéglátás alapszakon két félév a szakmai gyakorlat, amely turizmus, illetve vendéglátás tevékenységet folytató gazdálkodó szervezetnél vagy a felsőoktatási intézmény tanéttermében vagy tanszállodájában is elvégezhető, valamint egy félév lehet a magyar és külföldi felsőoktatási intézmény közötti megállapodás keretében szervezett, gyakorlatorientált külföldi részképzés. A nemzetközi gazdálkodás alapszakon a szakmai gyakorlat egy félév, de további követelmény legalább egy félév külföldön szerzett tapasztalat vagy nemzetközi környezetben megszerzett gyakorlat.

A gazdaságtudományi alapképzéseknél a finanszírozásban alapvető változások figyelhetők meg (2. ábra). A költségtérítéses hallgatók aránya 2007 és 2011 között 60-70 százalék között mozgott, azaz körülbelül kétharmadot tett ki, nappali tagozaton 40-50 százalékot, míg részidős képzésben 80-90 százalékot. Majd 2012-ben történt egy radikális lépés a kormány január 4-i döntése alapján: a gazdaságtudományi alapképzések nappali tagozatára szinte csak önköltséges (azaz tandíjas) hallgatók kerülhettek be: a 2011-es államilag finanszírozott 4900 helyett 250 fö (hasonlóan lecsökkentették a jogász- és egyes társadalomtudományi képzések felvételi keretszámait is). A döntés előzménye, hogy a 2008-as népszavazáson eldőlt, az államilag támogatott felsőfokú tanulmányokat folytató hallgatóknak nem kell képzési hozzájárulást fizetniük. 2012-ben a felvett hallgatók 98 százaléka önköltséges volt (a költségvetési források csökkentését a felsőoktatásban már a Széll Kálmán-terv is előirányozta), majd ez az arány fokozatosan csökkent, 2017-ben 85 százalékra és 2020-ban 53 százalékra (részidős képzésben 77 százalékra, nappalin 47 százalékra), azaz nagyjából visszaállt a 2007-2011 közötti helyzet. Megjegyzem, hogy 2011-ig az egyes intézményekre megállapított oktatási kapacitásszám alapján lett évente megadva, hogy hány főt vehet fel az intézmény államilag finanszírozott helyre (Polónyi [2019]).

\section{2. ábra}

A gazdaságtudományi alapképzésre felvett hallgatók száma tagozatok és finanszírozás szerint, 2006-2020 (fö)

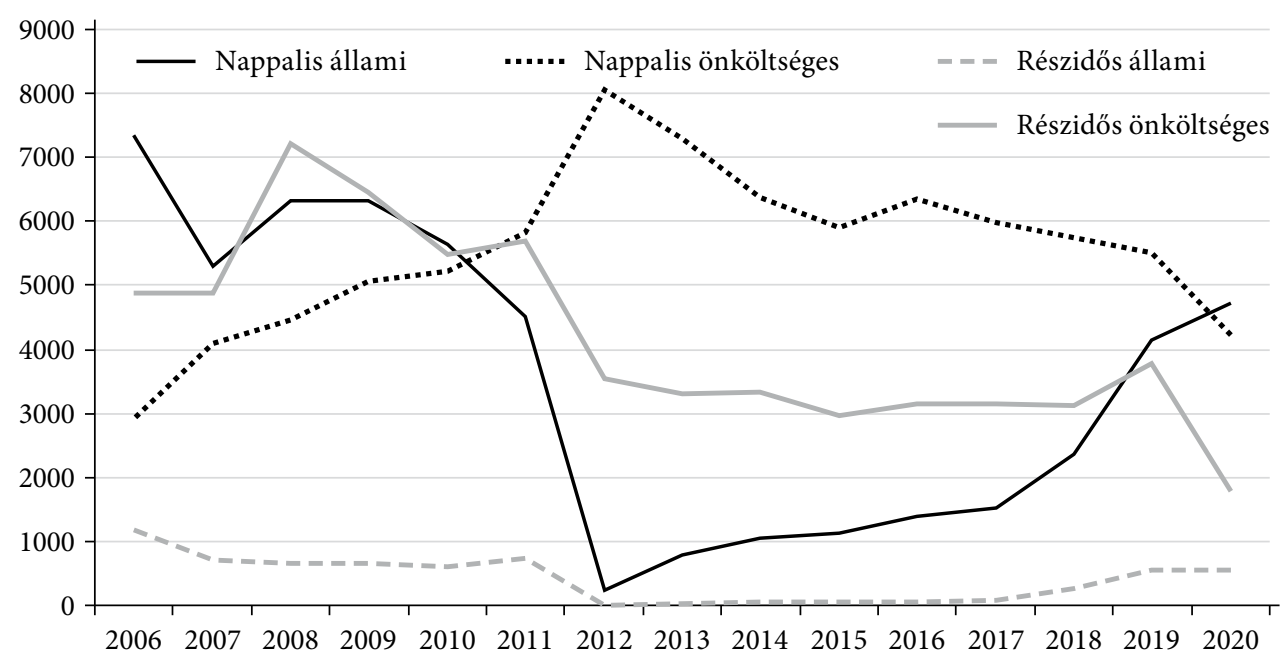

Forrás: Felvi alapján saját számítás. 
Az említett 2012. január 4-i kormánydöntés hatására a gazdaságtudományi alapképzések nappali tagozatára felvett önköltséges hallgatók száma a 2006-os háromezerről 2012-ben nyolcezer före nőtt, majd fokozatosan csökkenve 2020-ban négyezerre mérséklődött. Nappali tagozaton 2014-től újra be lehetett kerülni nagyobb számban államilag finanszírozott helyre, amennyiben a jelentkező elért egy előre megadott felvételi pontszámot. Például gazdálkodási és menedzsment szakon 2017ben 440, 2018-ban 428, míg 2019-ben és 2020-ban 400 pontot, illetve pénzügy és számvitel szakon sorrendben 450, 425 és 400 pontot. Az államilag finanszírozott helyekhez szükséges minimális felvételi pontszám csökkenése következtében fokozatosan emelkedett a felvett hallgatók száma, 2020-ban már közel ötezer fö került be ilyen módon nappali tagozatra.

A részidős képzésekre 2006-ban hatezer föt vettek fel, 2008-ban nyolcezer föt, majd 2012-ben meredeken lecsökkent ez szám: 2018-ig három-négy ezer között mozgott, de 2019-ben szintén kissé megugrott, részben ennek következtében 2020-ban kétezer före csökkent. Megjegyzem, hogy be lehet kerülni államilag finanszírozott helyekre levelező tagozaton is, azaz munka mellett folytatott képzésben, ami az intézmények bújtatott finanszírozásának tünik. 2006 és 2011 között államilag finanszírozott helyek magánintézményeknek is jutottak - évente körülbelül 800-900 hely -, de 2012-tôl csak állami vagy egyházi fenntartásúak kaphattak.

A felvett hallgatók számának tagozatonkénti és finanszírozás szerinti változásai eltérő módon hatottak az intézményekre. Az ezredfordulóra kiépült egy jelentős felsőoktatási kapacitás, amint bemutattuk, 2005-ben 87,3 ezer hallgató vett részt felsőfokú végzettséget nyújtó gazdaságtudományi képzésekben, 2018-ban viszont már csak 39,8 ezer. Az intézmények az oktatási kapacitásokat (termek, oktatók, számítógépek stb.) elsősorban a nappali tagozathoz igazították, mivel a részidős (levelező, esti és távoktatás) képzések föleg hétvégeken és kisebb óraszámban folynak.

A gazdaságtudományi alapképzéseknél a felvett hallgatók létszámának csökkenése, illetve az utóbbi években megfigyelhető stagnálása az intézmények között erőteljes átrendeződést indított el (Függelék F2. táblázat). Két intézmény kiemelkedik, az egyik a BGE, amely mindvégig megőrizte, sőt növelte az alapképzésben betöltött domináns szerepét, 2006 és 2011 között az összes tagozaton a hallgatók 22-24 százalékát vette fel, 2013-tól már 29-30 százalékát, nappali tagozatra pedig a 2006-os 27 százalékos arány megnövekedett 31-33 százalékra, sőt 2015-ben 36 százalékra. A másik a BCE, amely szintén képes volt részesedését növelni, az összes hallgató esetében 7-8 százalékról 13-14 százalékra, míg nappali tagozaton 9-10 százalékról 15-17 százalékra.

Az intézmények közötti átrendeződés jól kirajzolódik a nappali tagozatra felvett hallgatók számának alakulását tekintve (3. ábra). A 29 érintett intézményböl a BGE kiemelkedik, a többit a típusa (egyetem, szakegyetem és föiskola) és székhelye szerint érdemes megkülönböztetni, utóbbi a fövárosban vagy egy másik városban található (Függelék F1. táblázat). A fövárosban öt egyetemnek és hét szakegyetemnek (köztük a BGE-nek), míg vidéken kilenc egyetemnek és nyolc szakegyetemnek található a székhelye (az egyszerüség kedvéért a szakegyetemekhez soroljuk a föiskolákat is), de székhelyen kívüli képzöhelyeik több városban is müködhetnek. 


\section{3. ábra}

A gazdaságtudományi alapképzésben nappali tagozatra felvett hallgatók száma az intézmények típusa szerint, 2006-2020 (fö)

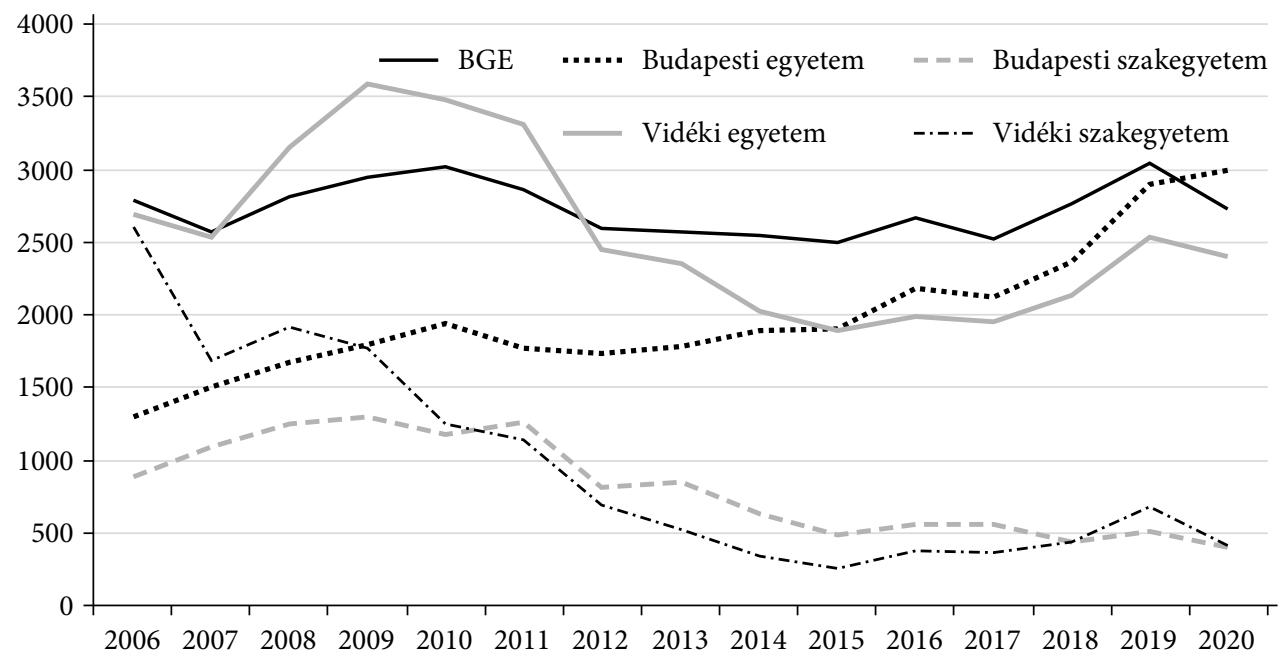

Forrás: Felvi alapján saját számítás.

A BGE nappali tagozatára felvett hallgatók létszáma viszonylag stabil, évente 2500 és 3000 fö között mozog, míg a fóvárosi egyetemeké kétszeresére nőtt, 2020-ban elérte a 3000 föt. A vidéki egyetemeké egy felfutást követően visszaesett, majd 2018-tól újra növekedésnek indulva érte el a 2006. évi 2500 fös létszámot. Jelentős visszaesés figyelhető meg a vidéki szakegyetemeknél, ahol 2500 föről 500 före csökkent a felvettek létszáma (sőt 2015-ben 250 före), továbbá a fövárosi szakegyetemeknél (a BGE nélkül számolva), ahol az utóbbi években szintén átlagosan 500 főt tudtak felvenni. Érzékelhetö, hogy a BGE mellett az egyetemek a nyertesei az átrendeződésnek, míg a többi szakegyetem és a föiskolák inkább a vesztesei, utóbbiak közül több (DUE, EJF, GDF, GFE, TPF, WSÜF) alig tudott felvenni néhány föt (Függelék F2. és F3. táblázat), ezáltal bizonytalanná vált a közgazdasági alapképzésük fenntarthatósága.

Az adatok alapján azonban az alapképzést is végző 14 egyetemből sem tudta mindegyik megerősíteni pozícióját: stabilizálta helyzetét három fővárosi (BCE, BMGE, ELTE) és öt vidéki székhelyü (DE, ME, PTE, SZE, SZTE) egyetem, a továbbiak stagnálnak vagy visszaszorulnak (például KE, SOE). Ennek a nyolc egyetemnek és a BGEnek, azaz együtt kilenc intézménynek az összes hallgatót tekintve a részesedése a kezdeti 48 százalékról 79 százalékra nőtt, sőt 2020-ban 84 százalék volt, míg nappali tagozaton 58 százalékról 80 százalékra emelkedett (a nappali tagozatos állami finanszírozottaknál 52 százalékról 94 százalékra). Látványos 2018-tól az ELTE felemelkedése, 2020-ban már a BGE és BCE mögött a harmadik helyre ért fel.

Az adatokból látható, hogy 2020-ban a további húsz intézménybe a hallgatók negyede-ötöde került, azaz jelentős intézményi koncentráció figyelhető meg. Megjegyzem, hogy a kilenc kiemelt intézmény között csak két korábbi föiskola található, a BGE és a győri egyetem (SZE, felemelkedését lásd Fekete-Rechnitzer [2019]), a többi hét már 
korábban is többkarú egyetemként müködött, a főiskolák (kivéve a METU-t) és a kisebb egyetemek nem tudták érdemben megerősíteni közgazdasági képzésüket.

A gazdaságtudományi alapképzést végző intézmények közötti átrendeződést a nappali tagozatra felvett, államilag finanszírozott hallgatók létszáma alapvetően befolyásolta (4. ábra). Már 2007-ben is csökkent 2,8 ezer fővel a felvehető létszám, de ez a csökkenés föleg a vidéki intézményeket érintette, a jobb alkupozícióval és lobbierővel bíró fővárosiakat kevésbé, sőt a fővárosi egyetemeken még nőtt is a létszám. Látványosan, mintegy negyedére visszaesett a vidéki szakegyetemekre és föiskolákra felvehető hallgatók száma (például KRF, SZF, Edutus). A 2012-től bevezetett, minimális felvételi pontszámhoz kötött új felvételi rendszer egyértelműen a fővárosi egyetemeknek, föleg a BCE-nek kedvezett, a többi intézmény a minimális felvételi pontszámok mérséklésekor, 2017 után tudott csak hallgatókat felvenni állami ösztöndíjas helyekre. Úgy vélem, hogy a 2012-es döntés és az azt követő felvételi rendszer nemcsak bizonytalanságot szült, de a mesterképzésre és az intézmények közötti átrendeződésre is kihatott, amire majd még kitérünk.

\section{4. ábra}

A gazdaságtudományi alapképzésben nappali tagozatra felvett, államilag finanszírozott hallgatók száma az intézmények típusa szerint, 2006-2020 (fö)

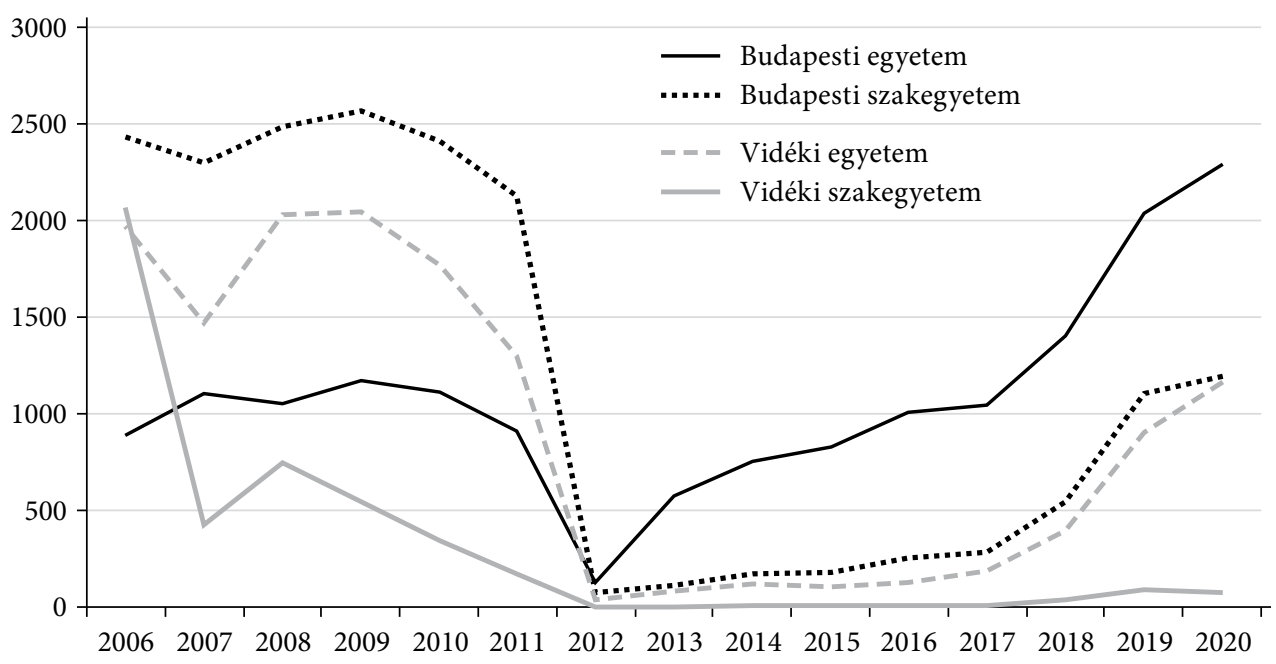

Forrás: Felvi alapján saját számítás.

2020-ban 28 intézmény vett fel gazdaságtudományi nappali tagozatos képzésre hallgatókat (a GDF csak részidős képzésre) (Függelék F3. táblázat). Csupán a BCE hirdette meg mind a hét alapszakot, négy intézmény hat alapszakot (BGE, ME, METU, PE), míg a többiek ennél kevesebbet, négy intézmény csak egy-egy szakot (DUE, EJF, IBS, NYE). A kiemelt kilenc intézményben az alapszakok többségét meghirdették, általában elegendő számban fel is tudtak venni hallgatókat (a turizmus-vendéglátás alapszakot az ELTE a szombathelyi képzőhelyén szervezi). Azoknál az intézményeknél igen kérdéses mind a képzés minősége, mind 
a finanszírozhatósága, ahol nappali tagozaton az alapszakonként felvett hallgatók száma nem éri el a 40-50 föt, főleg úgy, hogy a képzést több vidéki városban lévő képzőhelyeiken szervezik, sőt magyar és idegen nyelven is.

A gazdaságtudományi alapképzésre felvettek számát érdemben befolyásolta, amikor 2013-tól a felsőoktatási szakképzés felváltotta a korábbi felsőfokú szakképzést, 2020-ban 25 intézmény indította (lásd 1. táblázat). Négy olyan szakra lehet bekerülni (gazdálkodási és menedzsment, kereskedelem és marketing, pénzügy és számvitel, turizmus-vendéglátás), amelyről tovább lehet menni a megfelelő alapképzésbe, mivel minimum 30, maximum 90 kreditet el lehet fogadtatni. Fontos, hogy gazdálkodási és menedzsment, valamint kereskedelem és marketing szakon a sikeres végzéshez elegendő egyetlen alapfokú nyelvvizsga, a másik két szakon pedig egyetlen középfokú szaknyelvi vizsga. Meg kell jegyezni, hogy felsőoktatási szakképzés nemcsak a felsőfokú oktatási intézményekben, hanem a velük megállapodást kötő középiskolákban, szakképzö intézményekben mint egyéb képzési helyszíneken is végezhető.

$\mathrm{Az}$ is lényeges, hogy a felsőoktatási szakképzésben államilag finanszírozott helyre viszonylag könnyü bekerülni, évente a felvett hallgatók körülbelül 80 százaléka államilag finanszírozott, például 2020-ban a 4509 hallgatóból 3659 (közülük 1007 fö levelezőre jár) (Függelék F2. táblázat). Jelentős létszámról van szó, az alapszakos hallgatókhoz viszonyítva 35-40 százalékról. Sőt 2013-2017 között két és félszer többen kerültek be felsőoktatási szakképzésben államilag finanszírozott helyre, mint alapképzésben, csak 2019-től változott meg a helyzet. Valószínüleg több fiatal döntött úgy, hogy az önköltséges alapképzés helyett inkább a lakhelyén levő intézményben jár államilag finanszírozott felsőoktatási szakképzésre, ha mégis tovább tanul alapképzésben, akkor a kreditek elfogadtatása után már csak négy-öt félévig kell önköltséget fizetnie.

A hazai felsőoktatás elmúlt másfél évtizedes működése alatt igen sok és szerteágazó problémakör figyelhető meg a finanszírozástól a gazdálkodási megkötöttségeken át a kancellári rendszerig. A gazdaságtudományi alapképzésnél is több probléma felszínre került, amelyek közül négyet emelek ki: a felvételi tárgyak körét, a felkészült oktatók szűkösségét, a túl speciális szakokat és a szakmai gyakorlatok szervezését. A hazai közgazdasági felsőoktatás további, a mesterképzéseket is érintő vagy egyéb lényegesnek tartott kérdéseire később térek ki.

1. A felvételi tárgyak köre napjainkban igen széles, az érettségi tárgyak mint az üzleti alapszakok felvételi tárgyai között nagy a választási lehetőség, a következő nyolc tantárgy közül kell kettőt kiválasztani (emelt vagy középszintủ érettségit téve): földrajz, gazdasági ismeretek, informatika, matematika, történelem, ágazati szakmai érettségi vizsgatárgy (üzleti, közgazdasági), idegen nyelv, szakmai elökészítő vizsgatárgy (szintén üzleti, közgazdasági, informatikai). A felvételizők megpróbálják maximalizálni várható pontjaik összegét, emiatt igen sokan nem a nehéznek tartott matematikára koncentrálnak, hanem egyik tárgyuk például az idegen nyelv (amely a diplomához amúgy is szükséges), míg a másik a történelem (vagy a földrajz). Az üzleti szakok felvételi rendszerétől eltér az alkalmazott közgazdaságtan alapszak, ahol az egyik tárgy kötelezően az emelt szintü matematikaérettségi. Mivel üzleti alapszakokon a minimális felvételi pontszám 280, emiatt szinte bárki bekerülhet önköltséges képzésre, aki kettessel átmegy a matematikaérettségin, legfeljebb nem az első helyen 
megadott intézménybe. Amikor azonban a képzési és kimeneti követelményekben kötelezően elöírt statisztika, számvitel, pénzügy, mikroökonómia stb. tárgyaknál szembesülnek „számolási” és absztrakciós készségeik hiányosságaival, sokan feladják tanulmányaikat. A matematikát újra kötelező felvételi tárgyként kellene megadni az üzleti alapszakoknál, általában külföldön is elöírják (Kánnai és szerzőtársai [2010]), esetleg turizmus-vendéglátás szakon lehetne ettől eltérni. Alacsonyabb lenne ugyan az átlagos felvételi pontszám, de a lemorzsolódás is mérséklődne, megkímélve sok fiatalt és szüleiket a csalódástól és komoly anyagi kiadásoktól, továbbá az oktatókat is a felesleges terheléstől. Meg kell jegyezni, hogy 2012-től az állami ösztöndíjas helyhez szükség volt felvételi többletpontokra, amit föleg a módosabb szülők emelt érettségit tevö, nyelvvizsgákkal rendelkező, általában külön nyelvórára és korrepetálásra járó gyerekei értek el, míg a tehetséges, de szegényebb családokból jövők inkább az államilag finanszírozott műszaki, informatikai, agrár- stb. helyekre jelentkeztek.

2. Az oktatói kapacitás szükössége és felkészültségének hiányosságai az 1990-es években - a közgazdasági képzések hallgatói létszámának rohamos növekedésekor - azonnal nyilvánvalóvá váltak. Az állami intézményekben az oktatói státusok létszámkorlátozása miatt óraadókkal, másodállásokkal, doktoranduszokkal stb. próbálták a helyzetet kezelni, továbbá igen nagy létszámú szemináriumi csoportokat szerveztek (nemritkán 40-60 fővel). A hallgatói létszám csökkenését követően, 2012-től valamelyest változott a helyzet, de továbbra is nagy a lemorzsolódás (amint már volt arról szó, az alapképzésnél a sikeres befejezés körülbelül 52-54 százalékos), amit több tényezö befolyásol. Az egyik, hogy a legtöbb intézményben sem az elöadások, sem a szemináriumok látogatása nem kötelező, még nappali tagozaton sem, ezért a kevésbé motivált hallgatók a foglalkozásokat szelektíven látogatják, ami viszszaüt a számonkérés során. Az oktatók is beletörődtek, hogy a hallgatók nem vesznek részt az órákon, a hallgatók pedig elfogadták, hogy a másodállásokkal, egyéb megbízásokkal terhelt oktatók sem készülnek fel a legfrissebb ismeretekből. Ezért kötelezővé kellene tenni a szemináriumok látogatását. Természetesen ehhez az is kell, hogy kevesebb tárgy legyen, a kisebb létszámú hallgatói szemináriumokra az oktatók is felkészüljenek, továbbá a foglalkozás a hallgatók intenzív részvételével és „élményoktatással” társuljon. Több egyetemen vizsgaidőszakban mindegyik tárgyból hetente kell vizsgalehetőséget adni, ami az oktatókat nagyon leterheli, a hallgatók egy része „próba-szerencse” alapon vizsgázgat, ha többször nem sikerül, akkor legfeljebb majd felveszi a tárgyat a következö félévben.

Továbbá az oktatók jelentős része a régi beidegződések alapján tart előadásokat és vezet nagy létszámú szemináriumokat, ismeretek közlésére törekszenek képességfejlesztés helyett, holott sok hallgatónak a felkészültsége és képességei nem elegendők az elöadásokon elhangzottak befogadásához (a döntő többségben önköltséges hallgató jó vagy közepes tanuló volt középiskolában). Ráadásul a „tömegesedő” alapképzésben részt vevö közgazdász oktatók közül kevésnek van pedagógiai érzéke vagy végzettsége, kiválasztásuknál a tudományos teljesítmény áll előtérben (Sasvári és szerzőtársai [2021]). Az intézmények szükös forrásai és oktatói kapacitása sem teszi lehetővé a hatékony felzárkóztatást, a személyre szabott odafigyelést (tutor, supervisor), holott a középiskolából frissen kikerülők jelentős részének szüksége lenne rá. Sok 
hallgatónak a középiskolai „magolásról” nehéz átállni az összefüggések megértésére, a lényeg kiemelésére, önálló vélemény kialakítására.

A gazdaságtudományi képzésben robbanásszerüen megnőtt hallgatói létszámot nem követte az oktatók létszámának emelkedése, főleg a tudományos fokozattal $(\mathrm{PhD})$ rendelkezők hiányoztak. Amíg a korábbi közgazdászkarokon (BCE, PTE, ME) már kialakult a tudományos minősítettek köre, addig a föiskolákon és az újonnan alakuló képzőhelyeken kevesen voltak. Létrejöttek ugyan doktori iskolák - ez egyetemi karrá válás egyik alapfeltétele volt -, de az ezekből az iskolákból kikerülők közül kevesen maradtak a felsőoktatásban, részben a bérek, részben a megterhelő oktatás, a túlzott óraszámok miatt (Lengyel [2015]). Jellemzőnek tekinthető, hogy - a 2018. évi adatok alapján - az adjunktusok többsége saját egyetemén végzett mesterszakon, és ott is doktorált, külföldröl szinte senki sem tért vissza. Csak remélni lehet, hogy ez a belterjesség nem vezet kontraszelekcióhoz, de minden bizonnyal megnehezíti a legjobb hazai és nemzetközi oktatási és oktatásmódszertani gyakorlatok elterjedését.

A doktori iskolákkal nem rendelkező intézmények (szakegyetemek, főiskolák) pedig szinte megoldhatatlan problémákkal szembesültek, ugyanis alig lehet felvenni a doktori képzésekből kikerülő, tudományosan felkészített fiatalokat, ezért az egyetemekről próbáltak átcsábítani oktatókat, és a meglevő kollégákat próbálták rávenni a tudományos fokozat megszerzésére, vagy „névleg” alkalmazták külső intézmények minősített munkatársait. A felsőoktatási intézmények magukra lettek hagyva, oldják meg, ahogy tudják a sokszorosára nőtt hallgatói létszám miatti oktatói problémáikat, holott egy országos doktoriösztöndíj-program (például kutatóintézeti témavezetőket bevonva) és egy pedagógiai, oktatásmódszertani program jóval hatékonyabb lehetett volna.

3. Az üzleti alapszakok túl speciálisak, lényegében a BGE karainak (jogelőd föiskoláinak) képzési portfóliója él tovább. Bár elvileg lehetséges a menet közbeni szakváltás, de a gyakorlatban ritka, emiatt a bolognai rendszer egyik fö előnye nem képes érvényesülni, marad a lineáris elv, ha bekerül egy hallgató valamelyik szakra, akkor háromnégy év múlva ezt a diplomát kapja, vagy abbahagyja a képzést. Mivel a hat müködő üzleti alapszak első négy félévében minimális eltérésekkel ugyanazon alapozó és módszertani tárgyak szerepelnek (a képzési és kimeneti követelmények szerint is), ezért az intézmények jelentős részében összevont előadások vannak, együtt a különböző alapszakok hallgatóinak. Az alapszakok szerinti érdemi elkülönülés az ötödik félévtől kezdődik, de általában ezt követően is jelentős az átfedés a különböző szakok között (például a kötelezően választható tárgyak esetében). A túlzott specializáció - a hat üzleti alapszak - azért okoz gondot, mert az érettségizők többségének 18 évesen még csak felületes ismeretei vannak például az emberi erőforrások vagy a gazdálkodási és menedzsment alapszak lényegéről és az elhelyezkedési lehetőségekről.

Pozitív példát mutat a BCE 2021-ben meghirdetett integrált alapszakja, ${ }^{5}$ mivel a gazdálkodási és menedzsment alapszakba beolvasztják a kereskedelem és marketing, turizmus-vendéglátás (ezen belül a rendezvényszervezés) és emberi erőforrások alapszakokat, az ötödik és hatodik félévben meghirdetve az ezekhez a szakokhoz is illeszkedö

\footnotetext{
${ }^{5}$ https://www.uni-corvinus.hu/fooldal/kepzes/ba-bsc/\#gazdalkodasi-es-menedzsment.
} 
különféle specializációkat. Elegendőnek tűnik két üzleti alapszak, a gazdálkodási és menedzsment, továbbá a pénzügy-számvitel, egységesen hat félévvel, az ötödik félévtől pedig az intézmény rugalmasan szervezhessen specializációkat a munkaerőpiaci igények szerint, és adhasson diplomákhoz betétlapokat, amelyekben megjelenítik ezeket a specializációkat. Meg kell jegyezni, hogy a nemzetközi gyakorlat igen eltérő (több helyen például nyolc féléves az alapképzés, és két féléves a mesterképzés), nem könnyü adaptálni a sikeres példákat egy közepesen fejlett, duális gazdasági szerkezetű és ebből adódóan duális munkaerö-piacú ország számára (Szelényi [2015]).

4. Az üzleti alapszakoknál kötelező egy félévnyi, lényegében három hónapos összefüggö szakmai gyakorlat, általában a hetedik félévben, amely időszakban a szakdolgozatot is meg kell írni (30 kredit, amiből 10 kredit a szakdolgozat megírása). Úgy vélem, hogy az alapszakok többségén - például - a gazdálkodási és menedzsment szakosok nagyon eltérő tevékenységet végző vállalatoknál tudnak szakmai gyakorlatra menni, emiatt alig jelent későbbi pályájuk során előnyt, ha egyetlen speciális vállalat konkrét müködését megismerik. Amíg néhány multinacionális vállalatnál valóban élenjáró gyakorlati ismeretekre lehet szert tenni, azaz érdemi segítséget lehet kapni az elhelyezkedéshez, addig a hazai piacon „naponta túlélö”, kisebb magyar cégeknél erre minimális az esély, hiszen ők sem versenyképesek nemzetközileg. Talán egyedül a turizmus-vendéglátás alapszakon van értelme a hosszabb szakmai gyakorlatnak (ott is elegendő egy félév), fóleg külföldön, a többi alapszakon elég lenne hat-nyolc hét (nyáron). Meg kell jegyezni, hogy a kötelező szakmai gyakorlat a hasonló hét féléves alapképzésekben eltérő időtartamú, például a gazdaságinformatikuson nyolc hét, a műszaki menedzseren csak hat hét, pedig mindkét szakon a versenyszférának képeznek munkavállalókat. Ráadásul a szakmai gyakorlat után csak záróvizsgázni jön vissza a hallgató, így a gyakorlatban szerzett tapasztalatainak nincs érdemi viszszacsatolása a korábban tanult ismeretanyaghoz.

\section{A gazdaságtudományi mesterképzés}

A képzési és kimeneti követelményeket tartalmazó, a kézirat leadásakor hatályos EMMI-rendeletben a gazdaságtudományok képzési területen 21 mesterszak található, köztük az ötéves gazdaság- és pénzügy-matematikai elemzés osztatlan képzés, amely 2017-től indítható (2. táblázat). A többciklusú felsőoktatási rendszer bevezetésekor 13 mesterszak létezett, hozzájuk csatlakozott a sportközgazdász szak 2017-ben (az ellátásilánc-menedzsment szak 2016-ig logisztikai menedzsment néven futott). A mesterszakok köre 2020 végén kibővült további 6 szakkal, közülük egyedül a családpolitika és humán szakpolitikák gazdaságtana szakot hirdették meg 2020-ban, de nem vettek fel senkit. Mesterképzésre alapszakos diplomákkal rendelkezők jelentkezhetnek, de nemcsak a gazdaságtudományok képzési területéröl, hanem a gazdaságinformatikus, müszaki menedzsment, vidékfejlesztési agrármérnök stb. alapképzésből jövők is. Az EMMI-rendeletben, illetve az intézmények felvételi kiírásaiban szerepel, hogy az intézmény milyen alapszakos diplomákat fogad el teljes kreditértékkel, illetve a kreditátviteli bizottság milyen feltételeket támaszt más diplomák esetében. 
2. táblázat

A gazdaságtudományi mesterszakok főbb jellemzői

\begin{tabular}{|c|c|c|c|c|c|c|}
\hline \multirow[t]{2}{*}{ Mesterszak } & \multirow{2}{*}{$\begin{array}{c}\text { 2021-ben } \\
\text { meghirdetett } \\
\text { intézmények } \\
\text { száma }^{*}\end{array}$} & \multirow{2}{*}{$\begin{array}{l}\text { A félévek } \\
\text { száma }\end{array}$} & \multirow{2}{*}{$\begin{array}{l}\text { A kreditek } \\
\text { száma }\end{array}$} & \multicolumn{3}{|c|}{ Felvett hallgatók, 2020 (fö) } \\
\hline & & & & összes & $\begin{array}{c}\text { összesből } \\
\text { nappalis }\end{array}$ & $\begin{array}{l}\text { összesből } \\
\text { államilag } \\
\text { finanszírozott }\end{array}$ \\
\hline $\begin{array}{l}\text { Gazdaság- és pénzügy- } \\
\text { matematikai elemzés }\end{array}$ & $2(0)$ & 10 & 300 & 61 & 61 & 59 \\
\hline $\begin{array}{l}\text { Közgazdálkodás és } \\
\text { közpolitika }\end{array}$ & $2(1)$ & 4 & 120 & 99 & 65 & 82 \\
\hline Közgazdasági elemzö ${ }^{\star \star}$ & $1(1)$ & 4 & 120 & 39 & 39 & 37 \\
\hline $\begin{array}{l}\text { Nemzetközi gazdaság és } \\
\text { gazdálkodás }\end{array}$ & $9(6)$ & 4 & 120 & 184 & 89 & 163 \\
\hline $\begin{array}{l}\text { Biztosítási és pénzügyi } \\
\text { matematika }\end{array}$ & $1(0)$ & 4 & 120 & 21 & 21 & 21 \\
\hline $\begin{array}{l}\text { Ellátásilánc- } \\
\text { menedzsment }\end{array}$ & $5(2)$ & 4 & 120 & 286 & 98 & 265 \\
\hline Marketing & $10(4)$ & 4 & 120 & 522 & 257 & 474 \\
\hline $\begin{array}{l}\text { Master of Business } \\
\text { Administration (MBA) }\end{array}$ & $3(3)$ & 4 & 120 & 481 & 26 & 91 \\
\hline Pénzügy & $7(2)$ & 4 & 120 & 488 & 248 & 446 \\
\hline $\begin{array}{l}\text { Regionális és környezeti } \\
\text { gazdaságtan }\end{array}$ & $4(4)$ & 4 & 120 & 141 & 89 & 127 \\
\hline Sportközgazdász & $2(0)$ & 4 & 120 & 77 & 48 & 68 \\
\hline Számvitel & $5(0)$ & 4 & 120 & 236 & 97 & 214 \\
\hline Turizmusmenedzsment ${ }^{* *}$ & $6(5)$ & 4 & 120 & 62 & 30 & 53 \\
\hline Vállalkozásfejlesztés & $8(3)$ & 4 & 120 & 370 & 204 & 326 \\
\hline Vezetés és szervezés & $11(7)$ & 4 & 120 & 1121 & 462 & 974 \\
\hline $\begin{array}{l}\text { Családpolitika és } \\
\text { humán szakpolitikák } \\
\text { gazdaságtana }\end{array}$ & $1(1)$ & 4 & 120 & 0 & 0 & 0 \\
\hline Nemzetközi adózás & - & 4 & 120 & - & - & - \\
\hline Agrárközgazdász & - & 4 & 120 & - & - & - \\
\hline Kutatási menedzser & - & 2 & 60 & - & - & - \\
\hline Nemzetközi fejlesztés ${ }^{* *}$ & - & 4 & 120 & - & - & - \\
\hline Vállalat-gazdaságtan & - & 4 & 120 & - & - & - \\
\hline Mesterszakok együtt & - & - & - & 4188 & 1834 & 3400 \\
\hline
\end{tabular}

* Zárójelben az idegen nyelven meghirdetettek szerepelnek.

** Két idegen nyelv ismeretére van szükség az oklevélhez; a dőlten kiemelt szakok 2021-ben még nem lettek meghirdetve.

Forrás: Felvi alapján saját számítás. 
A mesterszakok esetében a közgazdaságtani és üzleti típusú elhatárolás kevésbé egyértelmü, de alkalmazható a Magyar Felsőoktatási Akkreditációs Bizottság (MAB) gyakorlata. Eszerint a doktori iskolák létesítésekor ${ }^{6}$ közgazdaság-tudományi doktori iskola alapozható a gazdaságtudományi mesterszakok közül a gazdaság- és pénzügymatematikai elemzés, a közgazdálkodás és közpolitika, a közgazdasági elemzö, valamint a nemzetközi gazdaság és gazdálkodás szakokra - ezeket nevezzük közgazdaságtani mesterszakoknak. Míg gazdálkodás- és szervezéstudományi doktori iskolánál a többi gazdaságtudományi mesterszak jöhet szóba, amelyeket üzleti jellegűnek tekinthetünk, továbbá itt is megjelenik a MAB felsorolásában a nemzetközi gazdaság és gazdálkodás, amely szak így mindkét típushoz sorolható.

A közgazdaságtani mesterszakok közül a gazdaság- és pénzügy-matematikai elemzés osztatlan képzést két egyetem hirdette meg (BCE, PTE), de eddig csak a BCE-re kerültek hallgatók. A közgazdálkodás és közpolitika mesterszakot több egyetem is elindította (BCE, NKE, SOE, SZTE), 2020-ban már csak a BCE és az NKE vett fel hallgatókat. A közgazdasági elemző szakot szintén több egyetem szervezte meg (BCE, BME, ELTE, PTE, KEE, PE), de szinte csak a BCE-n indul ilyen szak nappali tagozaton. Legnépesebb a nemzetközi gazdaság és gazdálkodás mesterszak, amelyet kilenc intézmény is meghirdetett (ANNYE, BCE, BGE, DE, ELTE, SOE, SZE, SZTE), de 2020-ban már csak négy egyetem tudott tíznél több főt felvenni nappali tagozatra.

A közgazdaságtani mesterképzés lényegében leszűkült egy osztatlan képzésre (csak a BCE-n indul), továbbá két viszonylag kis létszámú szakra (egy, illetve két egyetemen) és egy sok helyen meghirdetettre, amelyeken viszont nappali tagozaton kevesen tanulnak. 2020-ban gazdaságtudományi területen a mesterképzésre felvett hallgatók 9,1 százaléka került közgazdaságtani mesterszakokra, ha a nemzetközi gazdaság és gazdálkodástól eltekintünk, akkor csupán 3,3 százalékuk, többségük a BCE-re. Ezek az alacsony arányok nem meglepők, mivel közgazdaságtani alapszakon kevesen végeznek, az üzleti alapszakokon oktatott módszertani és elméleti közgazdaságtani ismeretanyagok pedig bevezető jellegüek, nem elegendők a közgazdaságtani mesterszakokon történő továbbtanuláshoz. Magyarországon lényegében egyedül a BCE-n figyelhető meg közgazdaságtani mesterképzés, az alapképzéshez hasonlóan a többi intézményben lényegében üzleti képzés folyik (Kovács-Görög [2019], Sándorné Kriszt [2014], Schepp [2019]).

A jelenleg müködö, üzletinek tekinthető mesterszakokat viszonylag sok intézmény meghirdeti - több helyen idegen nyelven is -, például a vezetés és szervezést 11, a marketinget 10, a „köztes” nemzetközi gazdaság és gazdálkodást 9 egyetem. Néhány mesterszakra sokan bekerülnek, például 2020-ban vezetés és szervezésre 1121 fö, marketingre 522 fö. Ellenben a biztosítási és pénzügyi matematika mesterszakot két helyen indították, a BCE-n és az ELTE Természettudományi Karán, 2020-ban csak az ELTEre vettek fel hallgatókat, míg 2021-ben csupán a BCE hirdette meg. Megfigyelhetö, hogy az üzleti mesterszakokon a hallgatóknak 40 százaléka jár nappali tagozatra, sőt

\footnotetext{
${ }^{6}$ https://www.mab.hu/wp-content/uploads/2019/11/DI-tudom\%C3\%A1ny\%C3\%A1gakmesterszakok.pdf.
} 
a Master of Business Administration képzésben csak 5 százalék, míg közgazdaságtani szakokon 66 százalék. Az is szembetűnő, hogy az üzleti mesterszakokon a hallgatók 80 százaléka államilag finanszírozott helyekre kerül, azaz levelezős képzésben is többségük tanulását a költségvetés fedezi.

Amint már volt arról szó, az alapszakok túl speciálisak, de az is megfigyelhető, hogy ezek folytatásaként jött létre több mesterszak, s ezekröl az alapszakokról teljes kreditérték beszámításával lehet tovább tanulni. Például az alkalmazott közgazdaságtaninak a közgazdasági elemző a folytatása, a kereskedelem és marketing alapszaknak a marketing mesterszak, a nemzetközi gazdálkodásnak a nemzetközi gazdaság és gazdálkodás, a turizmus-vendéglátásnak a turizmusmenedzsment, a pénzügy és számvitelnek pedig kettő is, a pénzügy és a számvitel mesterszakok. A gazdálkodási és menedzsment, valamint az emberi erőforrás alapszakokról elsősorban vezetés és szervezés, valamint vállalkozásfejlesztés mesterszakokra lehet továbbmenni, míg az ellátásilánc-menedzsment és a Master of Business Administration szakokra föleg müszaki vagy agrárvégzettségüek jelentkeznek. Az is elgondolkodtató, hogy 2020-ban turizmusmenedzsment mesterszakra kevesen kerültek be, csak 62 fö (nappalin mindössze 30 fö), holott alapszakon sokan végeznek, és hat egyetem is meghirdeti ezt a mesterszakot.

Nem az a gond, hogy vannak az alapszakokra közvetlenül épülő mesterszakok, inkább az, hogy ezekről a speciális alapszakokról nehéz másféle gazdaságtudományi mesterszakon folytatni a tanulást. A mesterképzésből a gazdaságtudomány sok lényeges, a hallgatókat várhatóan érdeklő és a munkaerőpiacon is fontos kérdésköre kimarad, például ingatlan-gazdaságtan, egészség-gazdaságtan, településgazdaságtan, információ-gazdaságtan, energiagazdálkodás. A legutóbbi szakbövítés már valamennyit javít a helyzeten, de még tovább kellene bővíteni a mesterszakok körét, például a tudományegyetemeken meglevő jogi, informatikai, társadalomtudományi műhelyek bevonásával. A szakok engedélyezését is rugalmasabbá kellene tenni, hogy az arra felkészült egyetemek meghirdethessenek külföldi hallgatóknak olyan képzéseket, amelyek esetében „piaci rést” érzékelnek, „az új globális kihívások lényegi átalakításokat indokolnának a mai, túlságosan egységesített képzésben" (Csaba [2013] 47. o.).

A gazdaságtudományi mesterképzésre felvett hallgatók között 2013-ig a részidösök aránya meghaladta a nappali tagozatosokét (52-54 százalék között mozgott), majd fokozatosan lecsökkent (2020-ban 44 százalékra) (5. ábra). A hallgatók többsége államilag finanszírozott képzésben vesz részt, $s$ amint említettük, arányuk mindvégig meghaladta a 80 százalékot. Az államilag finanszírozott részidősök létszáma eleinte közel kétszerese volt a nappali tagozatra járóknak, de 2017 után nagyjából egyformán alakult a számuk (körülbelül 1,5-1,7 ezer fö). Nappali tagozatos önköltséges helyekre évente közel 500 fö kerül, míg részidős képzésekben az önköltséges hallgatók száma 100 fö körül mozgott, azaz elenyésző volt (2020-ban 97 fö). Ez ellentmondás, hiszen a részidős hallgatók többsége munka mellett tanul, jövedelemmel rendelkezik, ezért képzésének költségét neki vagy a munkaadójának kellene fizetnie, nem az adófizetőknek. Főleg azért érthetetlen, mivel az alapképzésben igen nagy az önköltségesek aránya. 
5. ábra

A gazdaságtudományi mesterképzésre felvett hallgatók létszáma tagozatok és finanszírozás szerint, 2010-2020 (fö)

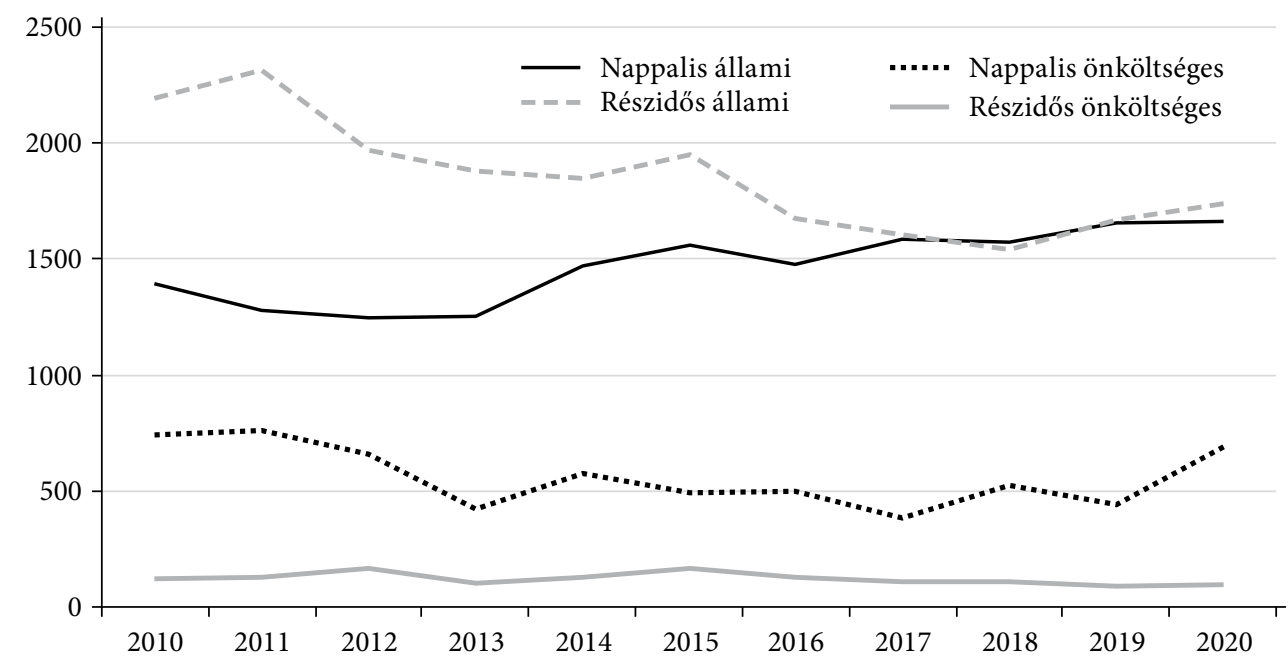

Forrás: Felvi alapján saját számítás.

A gazdaságtudományi mesterképzést az intézmények többsége megszervezte 2020-ban, és 21 intézménybe be is kerültek hallgatók (Függelék F4. táblázat). A felvett hallgatók összlétszáma mindvégig nagyjából egyenletes volt, négyezer fö körül mozgott, amelyen belül az államilag finanszírozottaké 3,5 ezer körül volt. Itt is érzékelhető bizonyos intézményi koncentráció, amíg 2010-2013 között az alapképzésben említett kilenc nagy egyetemre került a mesterképzésre felvett hallgatók 70 százaléka, addig 2020-ban már 78 százaléka. Megfigyelhető az ELTE 2018 utáni gyors felemelkedése, 2020-ban már a legtöbb hallgató oda került (föleg levelező képzésre), megelözve a BCE-t. Utóbbinak a részesedése mindvégig kiemelkedő, a 2010 utáni 20-21 százalékról 2017-ben felment 30 százalékra, majd 2020-ban lecsökkent 20 százalékra.

A gazdaságtudományi mesterképzésben nappali tagozatra felvett hallgatók számának az intézmények típusa szerinti bemutatásakor tisztább képet kapunk, ha a BCE-t mint domináns szereplőt külön vesszük (6. ábra). A BCE esetében is megfigyelhető egy 2012es visszaesés, majd a létszám visszakapaszkodott ezer före, de 2020-ban csak 774 hallgatót tudtak felvenni, nem kizárt, hogy a fenntartóváltás következtében. A kilenc vidéki székhelyü egyetemnél is ezer föről indult a felvettek létszáma, és fokozatos csökkenést követően 2014 után 400 fö körül stabilizálódott. A hét fövárosi székhelyű egyetemre (a BCE itt nem szerepel) felvettek létszáma 200-400 fö között mozgott, majd 2018 után az ELTE fellépése következtében fokozatosan megnőtt, 2020-ban 551 före. A fővárosi szakegyetemeken és föiskolákon (köztük a BGE-n) kezdetben 120-140 fö között volt a felvettek létszáma, ezt követöen meredeken lecsökkent, például 2018-ban 15 före, de 2020-ban is csupán 52 föt vettek fel (ebből a BGE-re két szakra együttesen 27 föt). A vidéki szakegyetemekre és föiskolákra felvett hallgatók száma mindvégig igen alacsony volt, 2016-ban például négy fö, azaz lényegében kiürültek mesterszakjaik, ennek ellenére folyamatosan meghirdetik őket. 
6. ábra

A gazdaságtudományi mesterképzésben nappali tagozatra felvett hallgatók létszáma az intézmények típusa szerint, 2010-2020 (fö)

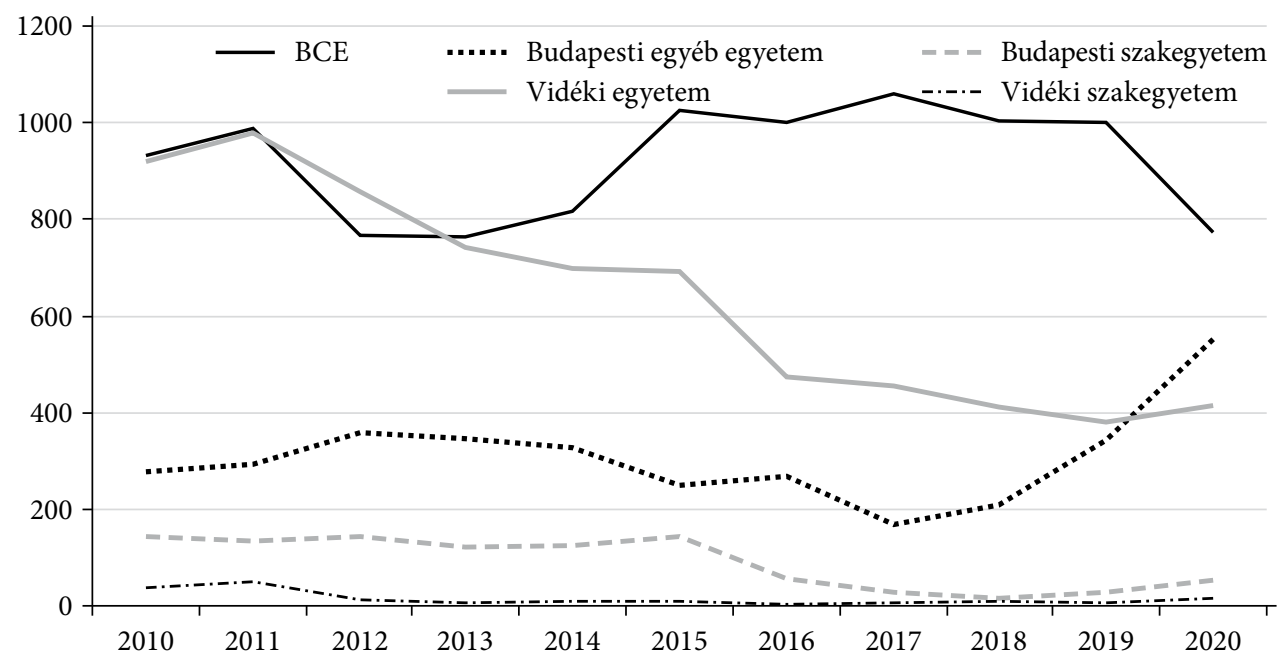

Forrás: Felvi alapján saját számítás.

A 21 intézmény közül a nyolc nagy egyetem (a BGE nélkül) részesedése a kezdeti 80 százalékról 90 százalékra nőtt, erőteljes a koncentrálódás, míg a szakegyetemeken és főiskolákon gyakorlatilag nem maradt életképes nappali tagozatos mesterképzés. Az intézményi koncentrálódás okai között említhető az intézmények nagyobb presztízse, a képzéseik színvonala, a nagy fóvárosi munkaerőpiac, a hallgatók tanulmány melletti munkavégzésének és kapcsolati tőkéje kiépítésének kiterjedt lehetőségei stb. A vidéki egyetemek mesterképzésének visszaesése annak is betudható, hogy az alapképzésben kevés volt 2012-töl az állami ösztöndíjas hallgatójuk (nemcsak nekik, de a korábban bázisuknak tekinthető vidéki föiskoláknak is), az önköltségesek pedig az alapszakot követően inkább a diákhitel visszafizetését lehetővé tevő munkát választották, nem pedig a további terheket jelentő mesterképzést (ezen van ugyan államilag finanszírozott hely, de az egyéb költségek - például lakhatási, megélhetési - is magasak).

A gazdaságtudományi mesterszakok 2020-as nappali tagozatos felvételi adatai több intézménynél igen szórt képzési szerkezetet mutatnak (Függelék F5. táblázat). Úgy vélem, hogy 15 fö alatt nem érdemes elindítani egy mesterszakot, ennél kisebb létszámnál gazdaságosan nem tartható fenn a képzés, legalábbis a hazai finanszírozási feltételek között nem garantálható a megfelelö minőségü oktatás (az adatok alapján 2020-ban az induló képzések 40 százalékában nem éri el a létszám a 15 főt). Természetesen az évi kétszeri felvételi, a februári kereszt- és a szeptemberi általános felvételi (továbbá pótfelvételi) esetén nehéz kalkulálni a várható összevont éves létszámot. Amíg a péntek délutáni és szombati napokon tartott levelező képzésben óraadókkal, azaz kis költségek mellett megszervezhető az oktatás, addig nappali képzésben szükség van föállású, a hallgatókkal hét közben is intenzíven foglalkozó, elismert 
tudományos teljesítményü oktatókra. A hiányukra is visszavezethető, hogy a szakegyetemeknek és föiskoláknak szinte alig van nappali tagozatos mesterszakos hallgatójuk, a náluk végzett alapszakos hallgatókat elsősorban arra tudják rábeszélni, hogy az államilag finanszírozott levelező tagozaton náluk tanuljanak.

$\mathrm{Az}$ is szembetűnő, hogy két olyan mesterszak nappali tagozatára - a nemzetközi gazdaság és gazdálkodás, valamint a turizmusmenedzsment - került be kevés hallgató 2020-ban, amelyeknek van felvezető alapszakjuk. (Meg kell jegyezni, hogy levelezö képzésre is viszonylag kevesen járnak, lásd 2. táblázat.) Amint ismertettük, a nemzetközi gazdálkodás és a turizmus-vendéglátás alapszakok egyaránt nyolc félévesek, amelyekből két-két félév a szakmai gyakorlat. A folytatásnak tekinthetö mesterszakokon a visszafogott jelentkezés abból is adódhat, hogy a két féléves gyakornoki munka után a hallgatók nem szívesen ülnek vissza az iskolapadba, továbbá hamar kimeríthetik az államilag finanszírozott keretet. Ugyanis az állami ösztöndíjjal vagy részösztöndíjjal (az önköltség felét kell megfizetni) támogatott hallgatók maximum 12 félévig tanulhatnak térítésmentesen, beleértve a felsőoktatási szakképzést, alap- és mesterképzést is. Ha a nyolc féléves alapképzést valamiért túllépi egy hallgató, akkor könnyen átcsúszik önköltséges képzésbe.

Az alapszakok hetedik félévi szakmai gyakorlata főleg a vidéki intézmények esetében fogja vissza a mesterszakra történő jelentkezéseket, mert az egyetem székhelyének helyet adó városban általában kevés olyan vállalat müködik, ahová a hallgatók féléves szakmai gyakorlatra mehetnének. Emiatt a hallgatók egy része másik városban, főleg a fövárosban talál gyakorlóhelyet, és mivel döntő részük önköltséges hallgató, ezért korábbi albérletüket feladva elköltöznek (föleg állami finanszírozású hallgatók nyerhetnek kollégiumi elhelyezést). Ezek a hallgatók már alig jelentkeznek korábbi intézményük nappali tagozatos mesterszakára, nem vállalják a visszaköltözést, albérletkeresést és a vele járó nehézségeket. Kétségkívül az is gyakori, hogy az arra alkalmas fiatalnak a szakmai gyakorlat végén a vállalat állást kínál, emiatt is sok esetben lemondanak a továbbtanulásról. A fövárosi intézmények esetében a kötelező szakmai gyakorlat kevésbé megterhelö, mivel hallgatóikat a fővárosban lévő vállalati központok és intézmények széles köre képes szakmai gyakorlatra fogadni, nem kell másik városba elköltözniük, hanem kollégiumukban, albérletükben maradhatnak.

A gazdaságtudományi mesterképzés évtizedes müködése során már érzékelhetővé vált a problémák többsége, a mesterszakokhoz közvetlenül kapcsolódók közül itt is négyet emelek ki: a közgazdaságtani szakok visszaszorulását, az üzleti mesterszakok téves pozicionálását, az okleveles közgazdász végzettség leértékelödését és az oktatáspolitika „rendszertelenségét”.

1. Kezdetben több intézmény is megszervezte a közgazdaságtani mesterszakokat, de ezek a szakok visszaszorultak, napjainkban lényegében csak a BCE-n folyik ilyen képzés, más intézményekben üzleti (gazdálkodástani) mesterszakok találhatók (kivéve a „köztes” nemzetközi gazdaság és gazdálkodást). Ennek a visszaszorulásnak az okai összetettek, egyrészt a közgazdaságtan elméleti és módszertani kérdései iránt érdeklődő tehetséges hallgatók közül többen külföldre mennek. Másrészt az üzleti alapszakokon végzettek közül kevesen kerülhetnek be teljes kreditérték beszámításával, többségüknek külön fel kellene vennie még további tárgyakat. 
Harmadrészt egy közepesen fejlett duális gazdaságban, mint a magyar, a vállalatok elsősorban konkrét gyakorlati feladatokra keresnek gazdasági szakembereket. Az is fontos, hogy az államigazgatás és az önkormányzati funkciók centralizációja következtében a helyi közösségek döntési kompetenciái, így döntés-elökészítő lehetőségei is beszükültek, inkább csak végrehajtó jellegü tevékenységeket végeznek, amelyekhez nem kellenek elemzéshez értő, társadalomtudományokban jártas, kritikus szellemü közgazdászok (Kornai [2019]).

2. Az üzleti mesterszakok téves pozicionálásának tartom, hogy széles körben rögzült az a vélemény, hogy a mesterképzésben az elmélet másodlagos, a „hogyanra” keresik a választ, és nem a "miértre”. Emiatt szinte csak az esettanulmányok, vállalati gyakorlati feladatok állnak a képzések elöterében, de mivel az alapképzésben és a szakmai gyakorlaton is ezzel foglalkoznak, ezért a hallgatók alig érzik a mesterképzés hozadékát. Alapvető, hogy a hallgatók a valós üzleti életből vett kurrens példákat, a legjobb nemzetközi gyakorlatokat ismerjék meg, és kritikusan dolgozzák fel, de ezek megértéséhez szükséges az adott ország társadalmi és gazdasági hátterének ismerete, azaz jogi, intézményi, kulturális, gazdaságtörténeti, szociológiai stb. elméleti jellegű nemzetközi ismeretanyag (Palánkai és szerzőtársai [2014], Szentes [2007]).

$\mathrm{Az}$ is megfigyelhető, hogy kevés az olyan oktatói és tudományos vénával megáldott gyakorlati szakember, aki óraadóként nemcsak saját speciális tapasztalatait adja tovább, hanem képes a különböző nemzetközi és vállalati gyakorlatokból általánosítható, rendszerbe foglalt következtetéseket is levonni. A felmérések szerint a nappali tagozatos üzleti mesterszakok hallgatóinak jelentös része, körülbelül 70 százaléka heti 25-30 órában dolgozik, sokszor nem az érdemi tapasztalatszerzés, hanem a jövedelem miatt (Takácsés szerzötársai [2017]). Nem marad idejük és energiájuk a társadalomtudományi jellegü kötelező irodalom érdemi feldolgozására és elmélyítésére, az „értelmiségi léthez” tartozó egyéb témakörök felfedezésére, szakmai vitákon való részvételre stb. Holott a hallgatók az együttlétük során rengeteget tanulnak egymástól, nemcsak ismereteket, hanem viselkedési formákat, értékrendet, csoportmunkát stb., enélkül pedig az üzleti mesterképzés inkább csak egy szakirányú továbbképzésnek felel meg.

3. A mesterszakon megszerezhető okleveles közgazdász végzettség leértékelödése több tényezőre vezethető vissza. Az alapszakok sikeres elvégzését követően az oklevél megnevezése: „közgazdász ... alapképzési szakon”, míg mesterszakoknál „okleveles közgazdász ... szakon”. Például a kereskedelem és marketing alapszakon végzetteké „közgazdász kereskedelem és marketing alapképzési szakon”, míg a marketing mesterszakot befejezőké „okleveles közgazdász marketingszakon”. A közvélemény "közgazdász” alatt föleg a korábbi egyetemi végzettséget érti, annak idején a föiskolákon üzemgazdász-diplomát adtak, a mostani alapszakos és mesterszakos diplomák között pedig nem tesz különbséget. Az is érzékelhető, hogy a mesterszakos oklevél devalválódott, egyrészt a végzett hallgatók egy részének a felkészültsége igen hiányos (több olyan intézmény is kiad mesterszakos közgazdászdiplomákat, ahol a színvonal igencsak kérdéses), másrészt elméleti közgazdaságtani és társadalomtudományi ismereteik felületesek, pedig egy közgazdász nem kerülheti meg a közpolitikai és etikai témák kritikus értelmezését. 
„Kezdettől fogva arra kell szoktatni minden fiatalt, hogy kritikusan tekintsen minden eléje tálalt gondolatra. Különösen indokolt ez a mi igencsak szerény eredményeket elért, bizonytalankodó, nagyokat tévedő társadalomtudományunkban. A mi diszciplínánkban kétkedéssel kell fogadni minden magabiztos állítást.” (Kornai [2011] 10. o.)

A két tudományterület egyre inkább elkülönül (Török [2014], Vörös [2014]), ezért az oklevelek elnevezésében is meg kellene jelennie ennek az elkülönülésnek. ${ }^{7}$ Zalai Ernő megfogalmazásában:

„Míg a gazdálkodástan elsősorban a gazdasági egységeken belüli jelenségeket elemzi, addig a közgazdaságtan a köztük levő kapcsolatokat szabályozó mechanizmusok és a makrogazdasági összefüggések kutatására összpontosít." (Zalai [2014] 903. o.)

Ezen a vitaülésen Chikán Attila megjegyezte:

„Belátható ugyan, hogy a közgazdaságtan és a gazdálkodástan között, tárgyukból következően, szerves kapcsolat van - ezt azonban a tudomány mai fejlettségi szintjén alig kezeljük. A szemléleti és módszertani eltérések egyaránt igen jelentősek, a két tudományterület lényegében egymástól szinte függetlenül fejlödik, s ebben nem is várható gyors változás." (Chikán [2014] 916-917. o.)

Már többen ötleteltek az oklevelek elnevezésein, érdemes lenne közös nevezöre jutni...

4. Az oktatáspolitika „rendszertelensége”, bizonyos szempontból következetlensége több tény alapján érzékeltethető. Az egyik az elöírt nyelvvizsgákhoz kapcsolódik, amint bemutattuk, alapszakon általában egy középfokú, a szak jellegének megfelelö szaknyelvi nyelvvizsga szükséges. Ehhez képest a mesterszakok többségénél elegendő egy középfokú angol nyelvvizsga, nem feltétel a szaknyelv ismerete, ami nélkül pedig az oktatás során felhasznált szakirodalom megismerése is gondot okozhat. De az is képtelenség, hogy a nemzetközi gazdálkodás alapszak sikeres elvégzéséhez két, legalább középfokú szaknyelvi nyelvvizsga szükséges, a nemzetközi gazdaság és gazdálkodás mesterszakhoz viszont elegendő egy középfokú angol nyelvvizsga. A műszaki, társadalomtudományi, agrár- stb. alapképzésből érkezők előtt megnyílt a lehetőség, hogy gazdaságtudományi mesterszakon folytathassák tanulmányaikat, de a mesterszakos diplomához számukra is elő kellene írni legalább az alapszakos követelményeket, például az üzleti szaknyelv ismeretét.

Szintén gond a nem megfelelő minőségellenőrzés. A formai szempontokat ellenőrzi ugyan bizonyos időközönként a MAB, de a néhány fős mesterszakok fennmaradhatnak, ${ }^{8}$ holott kérdéses, hogyan tudják az elöírt feltételeket biztosítani, például a doktori képzésre való felkészítést. Mivel az alkalmazott tudományok egyetemeinél (amelyeket szakegyetemnek rövidítettem) elöírás legalább két mesterszak fenntar-

\footnotetext{
${ }^{7}$ Az itt idézet mondatok az MTA Gazdálkodástudományi és Gazdasági Minősítő Bizottságának A közgazdaság-tudomány és a gazdálkodástudomány kapcsolata - nézetek, hitek, tévhitek és tanulságok a jövőre vonatkozóan címü tudománynapi konferenciáján hangzottak el, az előadásokat a Magyar Tudomány 2014. évi 6. száma közölte.

${ }^{8}$ A MAB csak véleményezési jogokkal rendelkezik, az Oktatási Hivatal hagyja jóvá, hogy hány fővel indíthat képzést egy intézmény.
} 
tása, ezért több intézmény mindent elkövet, hogy formailag megfeleljen a jogszabálynak. De mesterszakot csak ott szabadna engedélyezni, ahol a szakhoz illeszkedő doktori iskolák működnek, és a felvett hallgatók létszáma meghalad egy küszöbértéket (például 15 föt szakonként). 2020-ban 18 intézménybe vettek fel nappali tagozatra mesterszakos hallgatókat (Függelék F5. táblázat), közülük 14-ben müködik gazdaságtudományi doktori iskola, ezekbe az intézményekbe került a mesterszakos hallgatók 96 százaléka, a további 4 intézménybe alig került hallgató (összesen 69 fö). Az is érthetetlen, hogy a jelenlegi jogszabályok szerint mesterképzés csak nappali és levelező tagozaton végezhető, online távoktatásban nem. Remélhetö, hogy a pandémia által okozott helyzet arra is rávilágít, hogy ahol levelező képzést lehet folytatni, ott a hibrid (föleg online) oktatásnak is helye van, föleg az élethoszszig tartó tanulás szélesebb elterjesztése miatt.

\section{Összefoglaló megjegyzések}

A rohamosan átalakuló gazdasági-társadalmi feltételek (például a digitalizáció, ipar 4.0) hatására szinte minden országban törekszenek a felsőoktatás átalakítására, hogy megfeleljenek az új kihívásoknak. Várhatóan a most iskolába kerülő gyerekek többsége olyan szakmákban fog majd dolgozni, amelyeket ma még nem is ismerünk, ezért az oktatás, benne a felsőoktatás felelőssége óriási. Tanulmányunkban kitértünk a közgazdasági alap- és mesterképzések néhány alapvető problémájára, amelyekből kiindulva az alábbi általános megjegyzéseket tartjuk fontosnak.

1. A hazai felsőoktatási kapacitás gyorsan kibővült a 2000-es évek elejére, számtalan problémával és hiányossággal, de képes volt a hallgatók tömegeit oktatni, viszonylag sok városban. Ez a kapacitás napjainkra részben leépült, a felvett hallgatók száma mérséklödött. Ez a csökkenés a nappali tagozaton részben érthető a demográfiai hullám miatt, nagyon kevesen tanulnak viszont részidős képzésben munka mellett, mivel a képzések költségesek, és az utóbbi időben föleg csak a fővárosban és néhány regionális központban érhetők el. Az Európai Unió tagállamai sorában Magyarország az utolsók között szerepel a felsőoktatásban tanulók, a diplomások és a felnőttek továbbtanulási arányát tekintve, ami veszélyezteti az ország jövőbeli versenyképességét. Az ország a közepes fejlettség csapdájában ragadhat, ha a felsőoktatásban részt vevők arányát nem tudja növelni. A közgazdasági képzések népszerüek, a hallgatók negyede választja őket, a felsőoktatás szükségszerü bővítésekor lehetővé kellene tenni szélesebb körü elérhetőségüket.

2. A hazai felsőoktatás mindvégig alulfinanszírozott volt, a hallgatói létszám bővülésekor az állami ösztöndíjas helyekre felvett hallgatók után csak a müködési támogatást utalták át a következő évben. A közgazdasági képzőhelyek többsége újonnan jött létre, a szükséges terem-, iroda- és eszközfejlesztéseket föleg saját bevételekből vagy PPP konstrukcióban próbálták megoldani (ezek az épületek, eszközök nyilván állami tulajdonba kerültek), csak néhány intézmény kapott egyedi elbírálás alapján fejlesztési támogatást. Egyenlötlen versenyhelyzet alakult ki az újonnan létrejött és a régebb óta müködő - kiépült infrastruktúrával rendelkezö - intézmények között, 
utóbbiak a saját bevételek nagyobb részét tudták az oktatói feltételek javítására felhasználni. Az új képzőhelyek önköltséges képzések sorát indították, és a hallgatókat minél tovább „benntartották”, néha a képzés színvonalának rovására. Továbbá a szükös források miatt a költségek csökkentésére kényszerültek, így háttérbe szorult a szaknyelvi oktatás, a kiscsoportos szeminárium, a felzárkóztatás, a tehetséggondozás stb., de az alacsony bérek miatt az oktatói utánpótlás is egyre belterjesebbé vált. $\mathrm{Az}$ is feszültséget okozott sok helyen, hogy a közgazdasági karok, intézetek jelentős egyéb bevételt tudtak elérni a fizetős képzésekkel, de ezeket a forrásokat az intézmények vezetése átcsoportosította, keresztfinanszírozva az erős érdekképviseletű hagyományos, de veszteséges képzéseket, ezáltal viszont az üzleti képzések fejlődésének a lehetöségei is beszűkültek, sok helyen leépültek.

3. A közgazdaságtani képzések visszaszorultak az alap- és a mesterképzésben (lényegében egyetlen intézményben, a BCE-n találhatók). Úgy vélem, hogy szélesebb körben lenne szükség hazai közgazdaságtani képzésre. ${ }^{9}$ Természetesen neves külföldi intézményekben is tanulhatnak magyar fiatalok közgazdaságtant, majd hazatérésük után itthon is elhelyezkedhetnek, de amíg modellezés, ökonometria, nemzetközi gazdaságtan stb. kérdéskörökben a felkészültségük kiválóan alkalmazható, addig a hazai társadalmi-gazdasági viszonyok elemzése speciális ismereteket igényel, amelyeket csak itthon lehet megszerezni. A többkarú tudományegyetemeken (ELTE, DE, PTE, SZTE) nemzetközileg is elismert módszertani (matematikai, informatikai stb.) és társadalomtudományi (szociológiai, jogi stb.) műhelyek müködnek, amelyekre alapozva a közgazdaságtani szakoknak lenne létjogosultsága ezeken az egyetemeken.

4. A közgazdasági alap- és mesterképzésben egyaránt erőteljes intézményi és területi koncentrálódás figyelhető meg, ami részben arra vezethető vissza, hogy az itthon uralkodó szemlélet a felsőoktatás egészére piaci szolgáltatásként tekint. Úgy vélem, hogy az elitképzésnek tekinthető mesterképzésnél az intézmények piaci jellegü versenye és az ebből eredő koncentrálódás elfogadható, ami a nemzetközi versenyképességhez is szükséges (Török-Nagy [2021]). De a felsőoktatás alsó szintjein felerősödtek a koncentrálódás hátrányos társadalmi következményei (Lengyel-Varga [2018]). Amíg a nagyvállalatoknak nem okoz gondot a fővárosi intézményekből verbuválni kezdö közgazdászokat, addig a vidéki kisebb vállalatok többsége már gondban van, hiszen fejlődésük, nemzetköziesedésük nehezen képzelhető el legalább alapszakot végzett üzleti szakemberek nélkül. Hiába kínálnak ezeknek a kisebb vállalatoknak innovációs és egyéb forrásokat, ha kevés olyan munkatársuk van, akik rendelkeznek modern üzleti, szervezési és pénzügyi alapismeretekkel, vagy legalább elküldhetök ilyen továbbképzésekre, és idegen nyelven is tárgyalóképesek.

5. A tömegesedö felsőoktatási szakképzést és az üzleti alapképzéseket közszolgáltatásnak kellene tekinteni, hasonlóan a középfokú oktatáshoz, emiatt mindegyik megyei jogú városban - pozitív diszkriminációt alkalmazva - ezeket a képzéseket fenn kellene tartani, természetesen szem előtt tartva a képzések színvonalának

\footnotetext{
${ }^{9}$ Kónya István szóbeli közlése szerint a fejlett országokban a gazdaságtudományon belül körülbelül 10 százalék a közgazdaságtant tanulók aránya, azok is főleg az elitegyetemeken találhatók.
} 
javítását, a bejövő hallgatók felzárkóztatását. Ezáltal a kevésbé tehetős családok gyermekei is bekerülhetnének az államilag finanszírozott helyi üzleti alapszakokra. Az is lényeges, hogy a vidéki munkaerőpiacokon is folyamatos igény van a korábban érettségihez kötött, gazdasági ügyintézői jellegü munkahelyek betöltésére, amely igények így talán kielégíthetők lennének. Egyúttal ezek a képzőhelyek - mint a területfejlesztés eszközei - a vonzáskörzetükben élő felnőttek át- és továbbképzését, az élethosszig tartó tanulás intézményi hátterét is képezhetik.

6. A közgazdasági képzéseknél a bolognai szakstruktúra elsősorban a korábbi vezető intézmények kari és tanszéki érdekei szerint jöttek létre, és napjainkig konzerválódtak, nem reagáltak a megváltozott igényekre. Szükség lenne a felsőoktatási szakképzés, alapképzés és mesterképzés rendszerszintű újragondolására. Az üzleti alapképzésben elegendő lenne két alapszak, a szakmai ismeretek pedig specializációként legyenek választhatók. A mesterképzés viszont lehessen specializált, a munkaerőpiaci kereslethez rugalmasan illeszkedő, a szakirányú továbbképzésekhez hasonlóan változatos szakokat indíthassanak azok az egyetemek, ahol a minőségi képzés feltételei adottak (például doktori képzést is végeznek).

A címben is jelzett fenntartóváltás hatásai még nem értékelhetők, de a korábbi folyamatok fényében nehéz bizakodónak lenni. Nem vagyok oktatáspolitikai szakértő, de az elmúlt három évtizedben nem beszélhetünk átgondolt felsőoktatási politikáról. Különbözö javaslatok születtek ugyan az érzékelt problémák kezelésére, de ezek nem álltak össze rendszerré, a részintézkedések pedig sokszor kioltották egymást. Az intézmények sodródtak az eseményekkel, stratégiai tervezés helyett alkalmi lobbizással próbáltak talpon maradni, túlélni. A felsőoktatás gesztációs időszaka 10-15 év, ilyen időtávban kellene egy széles körü társadalmi konszenzuson alapuló jövőképet kialakítani az oktatási rendszerünkről. Hasonlót ahhoz, mint amit Klebelsberg Kunó alkotott a maga korában...

\section{Hivatkozások}

BARAKONYi KÁROLY [2009]: A business schoolok szerepváltozásai. Kihívások és változások a menedzserképzésben és az MBA-oktatásban. Vezetéstudomány, 40. évf. 1. sz. 2-15. o. https://doi.org/10.14267/VEZTUD.2009.01.01.

ChikÁN AtтiLA [2014]: Hidak a közgazdaságtan és gazdálkodástan között: a vállalatelméletek. Magyar Tudomány, 8. sz. 914-917. o.

Csaba LÁszLó [2013]: Kérdőjelek a közgazdaságtanban és oktatásában. Közgazdasági Szemle, 60. évf. 1. sz. 47-63. o.

DemCsÁKNÉ Ódor Zsuzsanna-HuszÁrik PÉTer [2020]: Lemorzsolódási vizsgálatok a felsőoktatásban. Oktatási Hivatal, Budapest.

DeRÉNyi ANDRÁs-Temesi József (szerk.) [2016]: A magyar felsőoktatás 1988 és 2014 között. Oktatáskutató és Fejlesztő Intézet, Budapest.

EU [2018]: Oktatási és képzési figyelő, 2018. Oktatás és képzés, Magyarország. Európai Unió, Luxembourg, https://ec.europa.eu/education/sites/education/files/document-library-docs/ et-monitor-report-2018-hungary_hu.pdf. 
Eurostudent [2018]: Social and Economic Conditions of Student Life in Europe. Eurostudent VI, 2016-2018. Synopsis of Indicators, http://www.eurostudent.eu/download_files/ documents/EUROSTUDENT_VI_Synopsis_of_Indicators.pdf.

Fekete Dávid-Rechnitzer János [2019]: Együtt nagyok. Város és vállalat 25 éve. Dialóg Campus, Budapest.

Hrubos ILdikó [2019]: Az európai felsőoktatási térség létrehozása mint az Európai Unió felsőoktatás-politikájának központi eleme. Educatio, 28. évf. 1. sz. 75-90. o. https://doi. org/10.1556/2063.28.2019.1.6.

Kánnai Zoltán-Pintér Miklós-Tasnádi Attila [2010]: Matematikaoktatás a bolognai típusú gazdasági képzésekben. Közgazdasági Szemle, 57. évf. 3. sz. 261-277. o.

Kornai János [2011]: Kapcsolatom a „Közgázzal”. A múlt, a jelen és a jövő. Köz-Gazdaság, 6. évf. 3. sz. 5-10. o.

KornAi János [2019]: A gondolat erejével? A közgazdászok szakmai és közéleti dilemmáiról. Közgazdasági Szemle, 66. évf. 2. sz. 117-133. o. https://doi.org/10.18414/ksz.2019.2.117.

KovÁcs PÉTER-Görög Vivien [2019]: Egyetemek hallgatói megtartóképessége. KözGazdaság, 14. évf. 1. sz. 24-29. o. https://doi.org/10.14267/retp2019.01.05.

Kováts Gergely-Temesi József (szerk.) [2018]: A magyar felsőoktatás egy évtizede, 20082017. BCE Nemzetközi Felsőoktatási Kutatások Központja, Budapest.

LENGY EL IMRE [2015]: Vágyak és realitások közt vergődve. A közgazdasági doktori képzésekről. Közgazdasági Szemle, 62. évf. 7-8. sz. 819-834. o.

Lengyel Imre-VARGA AtTila [2018]: A magyar gazdasági növekedés térbeli korlátai - helyzetkép és alapvető dilemmák. Közgazdasági Szemle, 65. évf. 5. sz. 499-524. o. https://doi. org/10.18414/ksz.2018.5.499.

OECD [2020]: Education at a glance. OECD, Párizs.

Palánkai Tibor-Simai Mihály-Szentes Tamás [2014]: A világgazdaságtan helye a Corvinuson. Köz-Gazdaság, 9. évf. 1. sz. 55-59. o.

Polónyi István [2019]: Anomáliák a felsőoktatás-finanszírozásban. Iskolakultúra, 29. évf. 6. sz. 88-95. o. https://doi.org/10.14232/iskkult.2019.6.88.

Polónyi István-Kozma TAmÁs [2020]: A magyar felsőoktatás fejlődése a rendszerváltás után. Magyar Tudomány, 4. sz. 502-512. o. https://doi.org/10.1556/2065.181.2020.4.8.

SÁnDORnÉ KRISZT Éva [2019]: A gazdaságtudományi képzések fejlesztési lehetőségeiről a magyar felsőoktatásban. Köz-Gazdaság, 14. évf. 1. sz. 6-15. o. https://doi.org/10.14267/ retp2019.01.03.

Sasvári Péter-Bakacsi Gyula-Urbanovics Anna [2021]: Az egyetemi előmenetel és a publikációs teljesítmény kapcsolata. Magyar Tudomány, 6. sz. 806-822. o. https://doi. org/10.1556/2065.182.2021.6.8.

Schepp Zoltán [2019]: A Pécsi Tudományegyetem gazdaságtudományi képzéseinek helyzetéről és fejlesztési lehetőségeiről. Köz-Gazdaság, 14. évf. 1. sz. 16-23. o. https://doi. org/10.14267/retp2019.01.04.

SZELÉNYi IVÁn [2015]: Jegyzetek az amerikai felsőoktatásról és a bolognai rendszerről. Századvég, 77. új évf. 3. sz. 5-30. o.

Szentes TAmás [2007]: A közgazdaságtan oktatásáról. Köz-Gazdaság, 2. évf. 2. sz. 141-170. o.

Takács SÁndor-Németh Márton-Juhászné Klér Andrea-ToArniczky Andrea [2017]: Az egyetem melletti munkavégzés segítő és gátló tényezői diákszemmel - kérdőíves felmérés a BCE, BGE és BME mesterszakos hallgatói körében. Vezetéstudomány, 48. évf. 3. sz. 39-55. o. https://doi.org/10.14267/veztud.2017.03.04.

TöRöк ÁDÁm [2014]: A tanítvány túlnő a mesteren? A közgazdaság-tudomány és gazdálkodástudomány változó kapcsolatrendszeréről. Magyar Tudomány, 8. sz. 906-908. o. 
TöröK ÁdÁM-Nagy Andrea Magda [2021]: A „nagy ugrás” a felsőoktatásban - Kína a nemzetközi verseny élmezőnyében? Közgazdasági Szemle, 68. évf. 4. sz. 375-398. o. https://doi. org/10.18414/ksz.2021.4.375.

Veres PÁL [2015]: Három fejezet a hazai felsőoktatás 25 éves történetéből. Köz-Gazdaság, 10. évf. 3. sz. 219-227. o.

Vörös JózsEF [2014]: A köz- és vállalatgazdaságtan alapját alkotó néhány kategória. Magyar Tudomány, 8. sz. 918-922. o.

ZALAI ERNő [2014]: Közgazdaság-tudomány és gazdálkodástudomány. Magyar Tudomány, 8. sz. 902-905. o.

\section{Függelék}

\section{F1. táblázat}

Magyarország államilag elismert felsőoktatási intézményei, ahol gazdaságtudományi képzések indulhatnak, 2020. december

\begin{tabular}{|c|c|c|c|}
\hline Rövidítés & Intézmény & Székhely & Székhelyen kívüli képzőhelyek ${ }^{*}$ \\
\hline \multicolumn{4}{|c|}{ I. ÁLLAMI EGYETEMEK } \\
\hline BMGE & $\begin{array}{l}\text { Budapesti Műszaki és } \\
\text { Gazdaságtudományi Egyetem }\end{array}$ & Budapest & Hatvan, Zalaegerszeg \\
\hline $\mathrm{DE}$ & Debreceni Egyetem & Debrecen & $\begin{array}{l}\text { Hajdúböszörmény, Kisvárda, } \\
\text { Nyírbátor, Nyíregyháza, Szolnok }\end{array}$ \\
\hline ELTE & Eötvös Loránd Tudományegyetem & Budapest & Szombathely \\
\hline $\mathrm{KE}^{* *}$ & Kaposvári Egyetem & Kaposvár & \\
\hline NKE & Nemzeti Közszolgálati Egyetem & Budapest & Baja \\
\hline $\mathrm{OE}$ & Óbudai Egyetem & Budapest & $\begin{array}{l}\text { Székesfehérvár, Salgótarján, } \\
\text { Kaposvár, Nyírbátor }\end{array}$ \\
\hline $\mathrm{PE}$ & Pannon Egyetem & Veszprém & $\begin{array}{l}\text { Kőszeg, Zalaegerszeg, } \\
\text { Nagykanizsa }\end{array}$ \\
\hline PTE & Pécsi Tudományegyetem & Pécs & $\begin{array}{l}\text { Kaposvár, Szekszárd, } \\
\text { Szombathely, Zalaegerszeg }\end{array}$ \\
\hline $\mathrm{SZIE}^{\star *}$ & Szent István Egyetem & Gödöllő & $\begin{array}{l}\text { Szarvas, Gyöngyös, Kisvárda, } \\
\text { Nyírbátor, Keszthely, Budapest }\end{array}$ \\
\hline SZTE & Szegedi Tudományegyetem & Szeged & Orosháza, Hódmezővásárhely \\
\hline \multicolumn{4}{|c|}{ II. Nem Állami EgYETEMEK } \\
\hline ANNYE & $\begin{array}{l}\text { Andrássy Gyula Budapesti Német } \\
\text { Nyelvü Egyetem }\end{array}$ & Budapest & \\
\hline $\mathrm{BCE}$ & Budapesti Corvinus Egyetem & Budapest & Székesfehérvár \\
\hline KEE & Közép-európai Egyetem & Budapest & \\
\hline KRE & Károli Gáspár Református Egyetem & Budapest & Kecskemét, Nagykőrös \\
\hline $\mathrm{ME}$ & Miskolci Egyetem & Miskolc & Ózd, Sátoraljaújhely \\
\hline SOE & Soproni Egyetem & Sopron & Tata \\
\hline SZE & Széchenyi István Egyetem & Győr & Mosonmagyaróvár \\
\hline
\end{tabular}


Az F1. táblázat folytatása

\begin{tabular}{llll}
\hline Rövidítés & Intézmény & Székhely & Székhelyen kívüli képzőhelyek $^{*}$ \\
\hline III. Állami AlKalmazott tudománYok EgYetEmei & \\
BGE & Budapesti Gazdasági Egyetem & Budapest & Hatvan \\
DUE & Dunaújvárosi Egyetem & Dunaújváros \\
EKE & Eszterházy Károly Egyetem & Eger & Sárospatak, Jászberény \\
NYE & Nyíregyházi Egyetem & Nyíregyháza & \\
\hline
\end{tabular}

IV. Nem ÁlLAMi ALKALMAZOTT TUDOMÁNYOK EGYETEMEI

\begin{tabular}{llll} 
EDUTUS & Edutus Egyetem & Tatabánya & Tata, Balatonfüred, Budapest \\
GFE & Gál Ferenc Egyetem & Szeged & Békéscsaba, Gyula, Szarvas, Budapest \\
KJE & Kodolányi János Egyetem & Orosháza & Székesfehérvár, Budapest \\
METU & Budapesti Metropolitan Egyetem & Budapest & \\
MILTON & Milton Friedman Egyetem & Budapest & \\
NJE & Neumann János Egyetem & Kecskemét & \\
\hline V. ÁlLAmi FőIsKola & & \\
EJF & Eötvös József Főiskola & Baja & \\
\hline
\end{tabular}

VI. NEM ÁLLAMI FÖISKOLÁK

GDF Gábor Dénes Főiskola Budapest Siófok

IBS IBS Nemzetközi Üzleti Főiskola Budapest

TPF Tomori Pál Főiskola Budapest Kecskemét

WSÜF Wekerle Sándor Üzleti Főiskola Budapest

* A székhelyen kívüli képzőhelyeknél dőlten szerepelnek azok a városok, ahol gazdaságtudományi képzések is folynak.

** 2021. február 1-jétől Magyar Agrár- és Élettudományi Egyetem (MAÉE, székhelye: Gödöllő), amely a Szent István Egyetem, a Kaposvári Egyetem, az Eszterházy Károly Egyetem Gyöngyösi Károly Róbert Campusa és a Pannon Egyetem Georgikon Kara összeolvadásából jött létre. Forrás: Felvi 2020. december 28-ától hatályos, egységes szerkezetű felvételi tájékoztatója.

F2. táblázat

Gazdaságtudományi alapképzésbe felvett hallgatók éves átlagos létszáma, zárójelben a nappali tagozatosoké, $2006-2020$ (fö)

\begin{tabular}{lcccccc}
\hline Intézmény & $2006-2011$ & 2012 & $2013-2017$ & 2018 & 2019 & 2020 \\
\hline ÁVF & $633(302)$ & $213(123)$ & $72(35)$ & - & - & - \\
BCE & $1264(1030)$ & $1427(1213)$ & $1538(1259)$ & $1695(1391)$ & $1783(1432)$ & $1508(1356)$ \\
BGE & $3933(2833)$ & $3358(2600)$ & $3264(2558)$ & $3472(2768)$ & $3932(3037)$ & $3482(2727)$ \\
BMGE & $451(451)$ & $316(316)$ & $487(487)$ & $383(383)$ & $482(482)$ & $605(605)$ \\
DE & $688(506)$ & $584(471)$ & $517(383)$ & $601(440)$ & $711(488)$ & $682(514)$ \\
DUE & $126(68)$ & $43(16)$ & $44(13)$ & $49(16)$ & $78(27)$ & $29(14)$ \\
EDUTUS & $752(406)$ & $396(232)$ & $163(82)$ & $147(81)$ & $134(62)$ & $77(50)$
\end{tabular}


Az F2. táblázat folytatása

\begin{tabular}{|c|c|c|c|c|c|c|}
\hline Intézmény & 2006-2011 & 2012 & 2013-2017 & 2018 & 2019 & 2020 \\
\hline EJF & $52(28)$ & $13(5)$ & $13(4)$ & $15(6)$ & $24(10)$ & $19(8)$ \\
\hline EKE & $211(115)$ & $122(78)$ & $114(64)$ & $175(82)$ & 355 (143) & $126(84)$ \\
\hline ELTE & $35(35)$ & $45(45)$ & $38(34)$ & 457 (419) & $802(757)$ & $819(788)$ \\
\hline GDF & $50(7)$ & $54(20)$ & $65(32)$ & $41(8)$ & $82(10)$ & $33(0)$ \\
\hline GFE & - & - & - & $7(2)$ & 55 (29) & $31(14)$ \\
\hline IBS & $102(102)$ & 87 (87) & $64(64)$ & $33(33)$ & $61(61)$ & $47(47)$ \\
\hline $\mathrm{KE}$ & $102(53)$ & $75(40)$ & $66(31)$ & $68(25)$ & $77(32)$ & $43(23)$ \\
\hline KJE & $787(406)$ & $342(143)$ & $241(71)$ & $254(60)$ & 407 (112) & $293(91)$ \\
\hline KRE & - & - & $114(51)$ & $174(75)$ & $180(67)$ & $127(72)$ \\
\hline $\mathrm{KRF}$ & $741(314)$ & $137(59)$ & $72(27)$ & - & - & - \\
\hline $\mathrm{ME}$ & $514(306)$ & $310(212)$ & 277 (207) & $328(236)$ & $404(293)$ & $292(238)$ \\
\hline METU & 868 (576) & $696(496)$ & $608(394)$ & $535(318)$ & $660(371)$ & $490(302)$ \\
\hline MILTON & $381(124)$ & $165(50)$ & $182(56)$ & $168(39)$ & $125(33)$ & $91(28)$ \\
\hline NJE & - & - & $52(34)$ & $246(157)$ & $341(238)$ & $128(128)$ \\
\hline NYE & 375 (97) & $108(41)$ & $93(34)$ & $103(34)$ & $161(59)$ & $72(29)$ \\
\hline $\mathrm{OE}$ & $186(146)$ & $220(156)$ & $208(144)$ & $139(90)$ & $208(158)$ & 229 (177) \\
\hline $\mathrm{PE}$ & 869 (534) & $468(332)$ & $350(221)$ & $369(233)$ & 406 (229) & $250(168)$ \\
\hline PTE & $588(412)$ & $454(348)$ & 384 (299) & $413(330)$ & $580(468)$ & $458(408)$ \\
\hline SOE & $518(323)$ & $360(275)$ & $212(146)$ & $142(77)$ & $158(95)$ & $65(65)$ \\
\hline SZE & $402(229)$ & $288(190)$ & $350(226)$ & $398(273)$ & $502(336)$ & $424(336)$ \\
\hline SZF & $716(295)$ & $319(121)$ & $93(44)$ & - & - & - \\
\hline SZIE & $1004(507)$ & $501(309)$ & $436(216)$ & $414(162)$ & $432(188)$ & $129(95)$ \\
\hline SZTE & $391(258)$ & 367 (276) & $413(311)$ & $500(356)$ & $615(401)$ & $620(547)$ \\
\hline TPF & $161(50)$ & $152(40)$ & $112(26)$ & $73(18)$ & $105(16)$ & $55(11)$ \\
\hline WSÜF & $139(0)$ & $218(0)$ & $146(7)$ & $98(16)$ & $105(14)$ & $51(11)$ \\
\hline Együtt & $\begin{array}{c}17041(10 \\
509)\end{array}$ & $\begin{array}{l}11838 \\
(8294)\end{array}$ & $\begin{array}{l}10787 \\
(7558)\end{array}$ & $\begin{array}{l}11497 \\
(8128)\end{array}$ & $\begin{array}{l}13965 \\
(9648)\end{array}$ & $\begin{array}{l}11275 \\
(8936)\end{array}$ \\
\hline $\begin{array}{l}\text { Felsőoktatási } \\
\text { szakképzés }\end{array}$ & - & - & $4060(3158)$ & 4878 (4051) & 5009 (4002) & 4509 (3659) \\
\hline
\end{tabular}

* Feltüntetve a 2015 végéig önálló intézményeket is.

** Zárójelben az összes állami finanszírozásra felvett hallgató létszáma szerepel; a SZIE adataihoz vettük a Tessedik Sámuel Főiskolát (2009-ben odacsatolták); az Edutus adatainál megtalálható a Harsányi János Főiskola (2011-ben csatlakozott); a METU jogelődei, a Budapesti Kommunikációs Főiskola és a Heller Farkas Gazdasági és Turisztikai Szolgáltatások Főiskolája 2009-ben egyesültek; az Általános Vállalkozási Főiskola (ÁVF) 2015-ben csatlakozott az IBS-hez; a Szolnoki Főiskola (SZF) 2016-ban csatlakozott a Kecskeméten levő, többször nevet váltó föiskolához, majd onnan 2019-ben átkerült a DE-hez; a Károly Róbert Főiskola (KRF) 2016 nyarán az Eszterházy Károly Egyetemhez (EKE) került.

Forrás: Felvi alapján saját számítás. 
F3. táblázat

Gazdaságtudományi alapszakokra 2020-ban felvett nappali tagozatos hallgatók száma (fö)

Intézmény Emberi Gazdálkodási Kereskedelem Nemzetközi Pénzügy Turizmus- Összes erőforrások és és marketing gazdálkodás és vendéglátás menedzsment számvitel

\begin{tabular}{|c|c|c|c|c|c|c|c|}
\hline $\mathrm{BCE}^{\star}$ & 71 & 570 & 119 & 186 & 204 & 96 & 1356 \\
\hline BGE & 182 & 544 & 593 & 396 & 362 & 650 & 2727 \\
\hline BMGE & - & 328 & - & 200 & 77 & - & 605 \\
\hline $\mathrm{DE}$ & - & 128 & 105 & 93 & 97 & 91 & 514 \\
\hline DUE & - & 14 & - & - & - & - & 14 \\
\hline EDUTUS & - & 12 & 21 & - & - & 17 & 50 \\
\hline EJF & - & 8 & - & - & - & - & 8 \\
\hline EKE & 12 & 32 & - & - & 16 & 24 & 84 \\
\hline ELTE & - & 207 & 205 & 267 & 98 & 11 & 788 \\
\hline GFE & - & 7 & - & - & 7 & - & 14 \\
\hline IBS & - & 47 & - & - & - & - & 47 \\
\hline $\mathrm{KE}$ & - & - & 10 & - & 13 & - & 23 \\
\hline KJE & 19 & 23 & - & - & - & 49 & 91 \\
\hline KRE & 46 & 26 & - & - & - & - & 72 \\
\hline $\mathrm{ME}$ & 23 & 72 & 53 & 30 & 34 & 26 & 238 \\
\hline METU & 49 & 75 & 78 & 18 & 11 & 71 & 302 \\
\hline MILTON & 8 & 11 & - & 9 & - & - & 28 \\
\hline NJE & - & 62 & 26 & 18 & 22 & - & 128 \\
\hline NYE & - & 29 & - & - & - & - & 29 \\
\hline $\mathrm{OE}$ & - & 98 & 79 & - & - & - & 177 \\
\hline $\mathrm{PE}$ & 23 & 45 & 34 & 10 & 28 & 28 & 168 \\
\hline PTE & - & 169 & 107 & - & 76 & 56 & 408 \\
\hline SOE & - & 16 & 10 & 6 & 16 & 17 & 65 \\
\hline SZE & - & 176 & 97 & - & - & 63 & 336 \\
\hline SZIE & - & 23 & 28 & - & - & 44 & 95 \\
\hline SZTE & - & 157 & 145 & - & 141 & 104 & 547 \\
\hline TPF & - & 8 & - & 1 & 2 & - & 11 \\
\hline WSÜF & 2 & 4 & 5 & - & - & - & 11 \\
\hline Együtt $^{*}$ & 435 & 2891 & 1715 & 1234 & 1204 & 1347 & 8936 \\
\hline
\end{tabular}

* A BCE adatában szerepel az alkalmazott közgazdaságtan alapszakra felvett 110 fö. Forrás: Felvi alapján saját számítás. 
F4. táblázat

Gazdaságtudományi mesterképzésbe felvett hallgatók éves átlagos létszáma, zárójelben a nappali tagozatosoké, 2010-2020 (fö)

\begin{tabular}{|c|c|c|c|c|c|}
\hline Intézmény & 2010-2013 & 2014-2017 & 2018 & 2019 & 2020 \\
\hline ANNYE & $10(10)$ & $11(11)$ & $6(6)$ & $7(7)$ & $11(11)$ \\
\hline ÁVF & $47(21)$ & 47 (19) & - & - & - \\
\hline $\mathrm{BCE}^{*}$ & $888(863)$ & 1017 (975) & 1077 (1004) & 1079 (999) & $831(774)$ \\
\hline BGE & 362 (109) & $395(65)$ & $293(6)$ & $214(14)$ & $311(27)$ \\
\hline BMGE & 411 (249) & $511(169)$ & $244(44)$ & $261(68)$ & $249(73)$ \\
\hline $\mathrm{DE}$ & $288(162)$ & 237 (118) & $227(83)$ & $225(106)$ & $256(104)$ \\
\hline EDUTUS & $30(0)$ & $9(0)$ & $11(0)$ & $9(0)$ & $7(0)$ \\
\hline EKE & $* *$ & $10(1)$ & $31(0)$ & $37(3)$ & $39(11)$ \\
\hline ELTE & $27(27)$ & $27(27)$ & 348 (99) & $637(216)$ & $980(431)$ \\
\hline IBS & $* *$ & $* *$ & $* *$ & $1(1)$ & - \\
\hline $\mathrm{KE}$ & $28(26)$ & $16(11)$ & $32(26)$ & $24(22)$ & $42(37)$ \\
\hline KEE & $15(15)$ & $15(15)$ & $10(10)$ & $8(8)$ & - \\
\hline KJE & $5(1)$ & $13(4)$ & $17(8)$ & $8(2)$ & $22(5)$ \\
\hline KRF & $71(26)$ & $26(2)$ & - & - & - \\
\hline $\mathrm{ME}$ & $223(107)$ & $182(76)$ & $191(61)$ & $147(29)$ & $142(32)$ \\
\hline METU & $64(5)$ & $62(5)$ & $95(9)$ & $153(13)$ & $174(25)$ \\
\hline MILTON & $14(0)$ & $10(0)$ & $8(0)$ & - & - \\
\hline NJE & $* *$ & $2(0)$ & $70(0)$ & $59(0)$ & $75(0)$ \\
\hline NKE & - & - & $88(35)$ & $32(32)$ & $58(35)$ \\
\hline $\mathrm{OE}$ & $103(19)$ & $106(31)$ & $67(18)$ & $57(18)$ & $74(28)$ \\
\hline $\mathrm{PE}$ & $242(67)$ & $143(33)$ & $103(24)$ & $107(21)$ & $105(25)$ \\
\hline PTE & $344(185)$ & $212(112)$ & $137(64)$ & $155(56)$ & $180(64)$ \\
\hline SOE & $145(35)$ & $76(13)$ & $36(6)$ & $34(2)$ & $22(2)$ \\
\hline SZE & $200(88)$ & $201(83)$ & $160(54)$ & $185(52)$ & $207(60)$ \\
\hline SZIE & $452(82)$ & $470(54)$ & $404(31)$ & $324(27)$ & $281(16)$ \\
\hline SZTE & $190(124)$ & $120(81)$ & $91(61)$ & $95(64)$ & $122(74)$ \\
\hline Együtt & $4157(2218)$ & 3916 (1903) & 3745 (1649) & $3858(1760)$ & $4188(1834)$ \\
\hline
\end{tabular}

* A BCE adatában szerepelnek a gazdaság- és pénzügy-matematikai elemzés osztatlan képzésre felvettek adatai is.

${ }^{* *}$ Meghirdették, de senkit nem vettek fel.

Forrás: Felvi alapján saját számítás. 
F5. táblázat

A gazdaságtudományi mesterszakok nappali tagozatára felvett hallgatók száma, 2020 (fö)

\begin{tabular}{|c|c|c|c|c|c|c|c|c|c|c|c|c|}
\hline Intézmény & ELM & MBA & MK & NG & $\mathrm{PZ}$ & RKG & SP & $\mathrm{SZ}$ & TM & VF & VSZ & Együtt \\
\hline ANNYE & - & - & - & 5 & - & - & - & - & - & - & 6 & 11 \\
\hline $\mathrm{BCE}^{*}$ & 40 & 12 & 95 & 20 & 94 & 47 & 30 & 44 & - & 128 & 134 & 774 \\
\hline BGE & - & - & - & 11 & - & - & - & - & 16 & - & - & 27 \\
\hline BMGE & - & - & - & - & 8 & 34 & - & - & - & - & 31 & 73 \\
\hline $\mathrm{DE}$ & 18 & - & 14 & 4 & - & - & 18 & 11 & - & 14 & 25 & 104 \\
\hline EKE & - & - & - & - & - & - & - & - & 3 & 2 & 6 & 11 \\
\hline ELTE $^{* *}$ & - & - & 86 & 25 & 84 & - & - & 39 & - & - & 176 & 431 \\
\hline $\mathrm{KE}$ & - & - & - & - & 29 & 8 & - & - & - & - & - & 37 \\
\hline KJE & - & - & - & - & - & - & - & - & 1 & 4 & - & 5 \\
\hline ME & 6 & 7 & 12 & - & - & - & - & - & - & 2 & 5 & 32 \\
\hline METU & - & 7 & 10 & - & - & - & - & - & 5 & - & 3 & 25 \\
\hline $\mathrm{OE}$ & - & - & - & - & - & - & - & - & - & 28 & - & 28 \\
\hline $\mathrm{PE}$ & - & - & 2 & 3 & - & - & - & 3 & 5 & - & 12 & 25 \\
\hline PTE & - & - & 16 & - & 16 & - & - & - & - & 4 & 28 & 64 \\
\hline SOE & - & - & - & 1 & - & - & - & - & - & 1 & - & 2 \\
\hline SZE & 34 & - & 3 & 3 & - & - & - & - & - & - & 20 & 60 \\
\hline SZIE & - & - & - & - & - & - & - & - & - & - & 16 & 16 \\
\hline SZTE & - & - & 19 & 17 & 17 & - & - & - & - & 21 & - & 74 \\
\hline Együtt $^{* * *}$ & 98 & 26 & 257 & 89 & 248 & 89 & 48 & 97 & 30 & 204 & 462 & 1834 \\
\hline
\end{tabular}

Rövidítések: ELM - ellátásilánc-menedzsment, MBA - Master of Business Administration, MK - marketing, NG - nemzetközi gazdaság és gazdálkodás, $\mathrm{PZ} \mathrm{-} \mathrm{pénzügy,} \mathrm{RKG} \mathrm{-} \mathrm{regio} \mathrm{-}$ nális és környezeti gazdaságtan, SP - sportközgazdász, SZ - számvitel, TM - turizmusmenedzsment, VF - vállalkozásfejlesztés, VSZ - vezetés és szervezés.

* A BCE együttes adatában szerepel a gazdaság- és pénzügy-matematikai elemzésre felvett 61 fö, a közgazdasági elemző mesterszakra felvett 39 fő, továbbá a közgazdálkodás és közpolitika mesterszakra felvett 30 fö.

** Az ELTE együttes adatában szerepel a biztosítási és pénzügyi matematika mesterszakra felvett 21 hallgató.

*** Az NKE közgazdálkodás és közpolitika mesterszakának 35 hallgatójával együtt.

Forrás: Felvi alapján saját számítás. 